\title{
Stress in childhood and the risk of \\ type 1 diabetes
}

\author{
Maria Nygren
}

Division of Clinical Sciences,

Department of Clinical and Experimental Medicine,

Faculty of Medicine and Health Sciences,

Linköping University, SE-581 83 Linköping

Linköping 2015 
(C) Maria Nygren, 2015

Puplished articles have been reprinted with the permission of the respective copyright holder:

Paper 1 (C) Society for Reproductive and Infant Psychology 2012

Paper 2 (C) Elsevier Ireland Ltd. 2013

Paper 3 (C) Springer-Verlag Berlin Heidelberg 2015

Cover illustration by Eva Perlskog

ISBN 978-91-7685-973-5

ISSN 0345-0082

Printed by LiU-Tryck, Linköping 2015. 


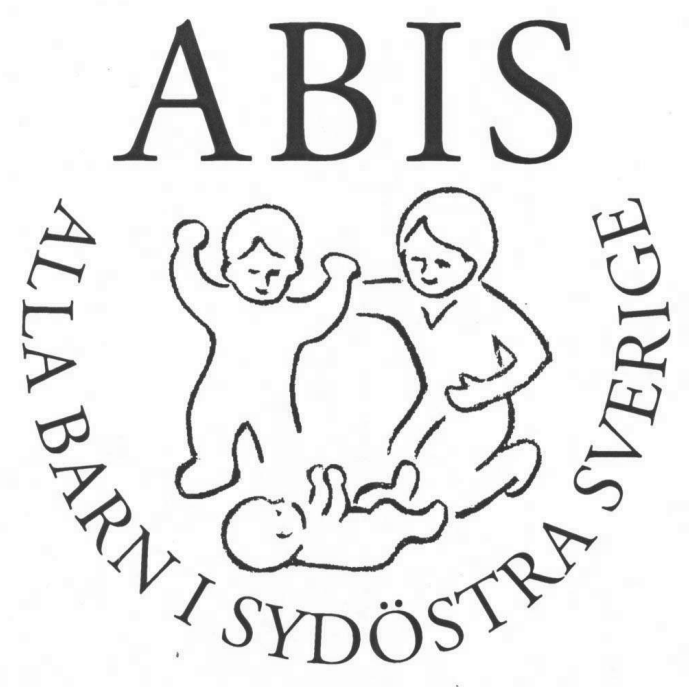





\section{Table of Contents}

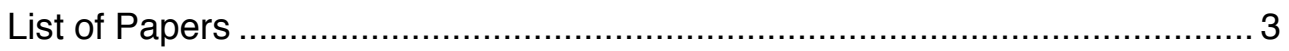

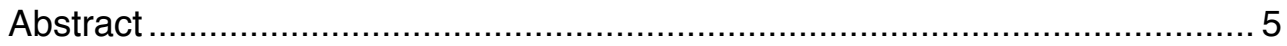

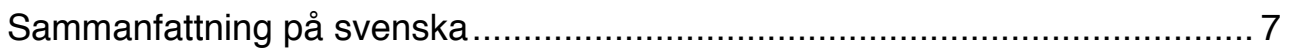

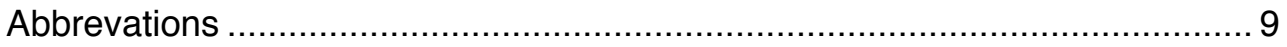

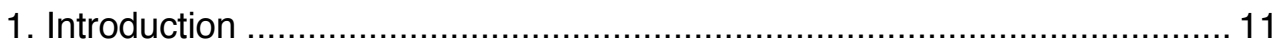

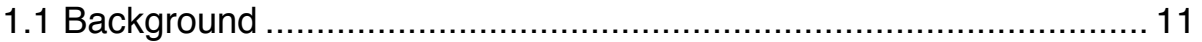

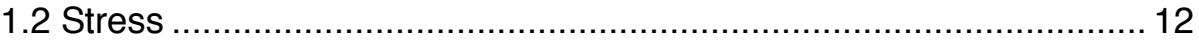

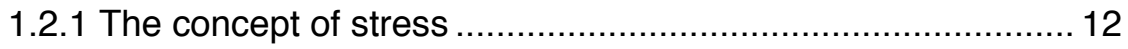

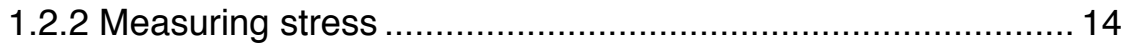

1.2.3 Psychological stress in children ........................................... 16

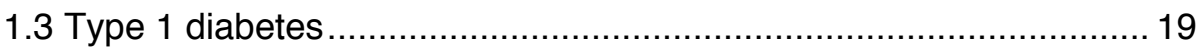

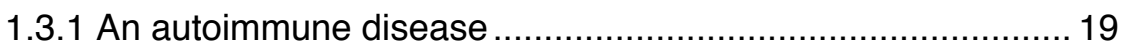

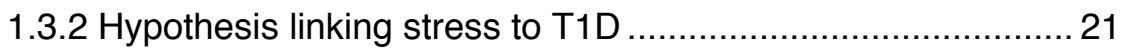

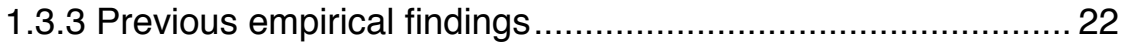

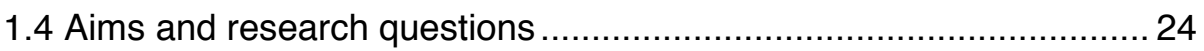

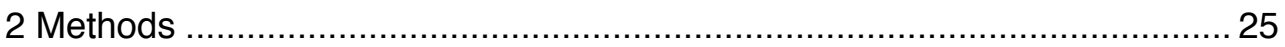

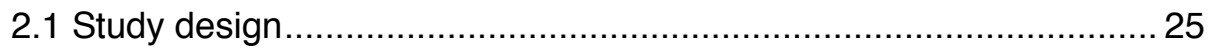

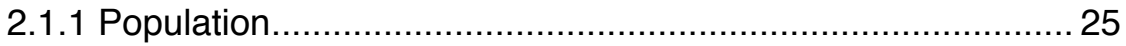

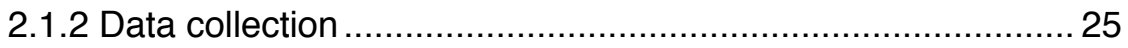

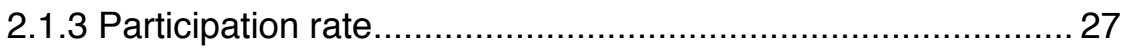

2.1.4 Descriptive statistics of the ABIS-sample ............................ 29

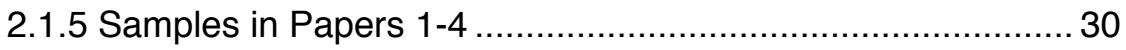

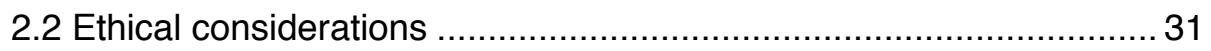

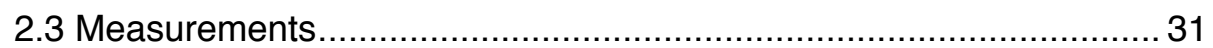

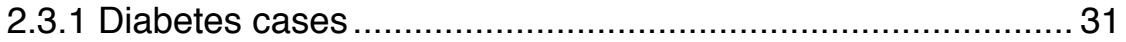

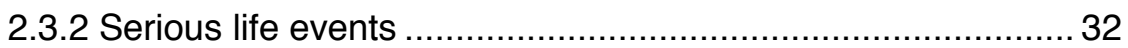

2.3.3 Psychological stress among parents .................................. 32

2.3.4 The child's temperament and mental health........................... 37

2.3.4 Socio-demographic factors ................................................. 39

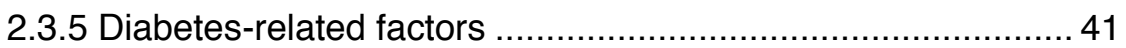

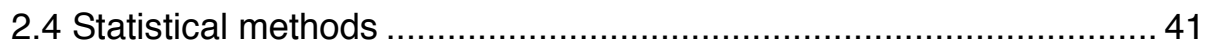

2.4.1 Statistical methods in Papers 1-4 …...................................... 41

2.4.2 Statistical methods in the frame-work.................................. 42 
3 Results 43

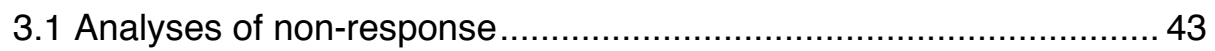

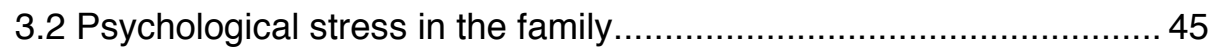

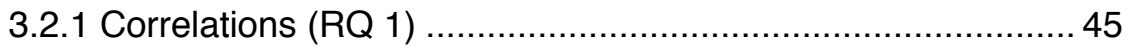

3.2.2 Parents' stress and child's mental health (RQ 2) ................. 45

3.3 Stress and the risk of type 1 diabetes ............................................ 46

3.3.1 Serious life events (RQ 3) ............................................... 46

3.3.2 Psychological stress among parents (RQ 4) ....................... 47

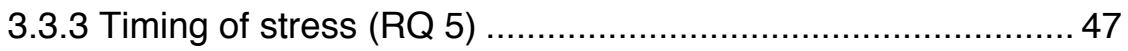

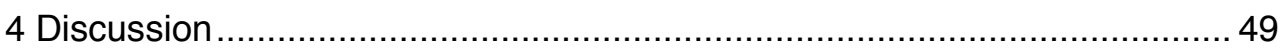

4.1 Measurements of stress - reliability and validity ............................. 49

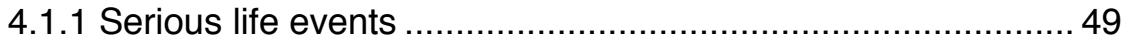

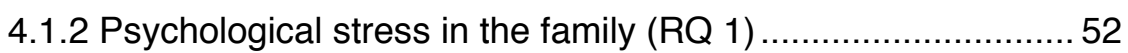

4.1.3 Proxies for psychological stress of the child (RQ2) ................56

4.2 Stress and the risk of type 1 diabetes ............................................. 58

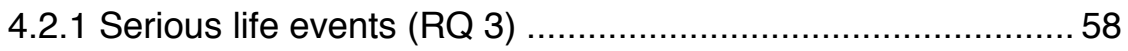

4.2.2 Psychological stress among parents (RQ 4) ........................ 60

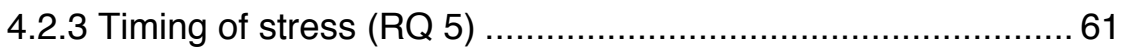

4.2.4 Stress in relation to genetic risk of T1D ................................ 62

4.2.5 The significance of SLEs and possible prevention ..................63 63

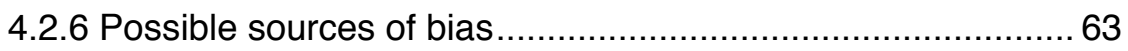

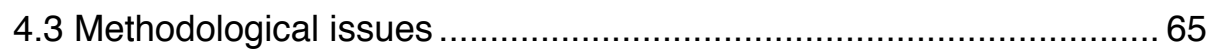

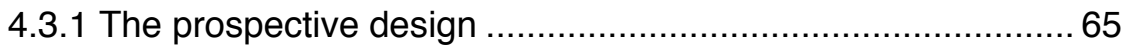

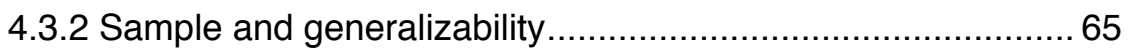

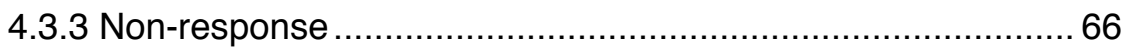

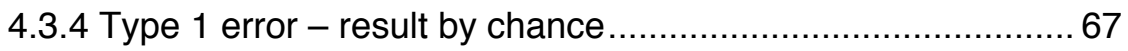

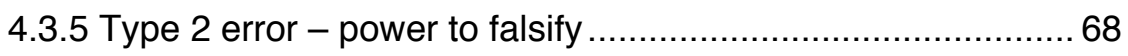

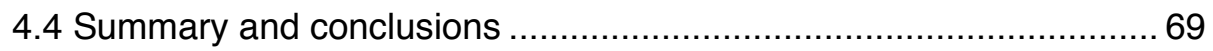

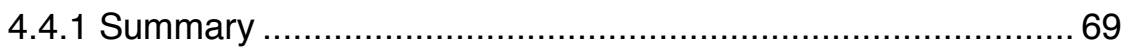

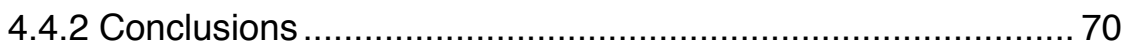

4.4.3 More general conclusions................................................... 70

4.4.4 Suggestions for future research ....................................... 71

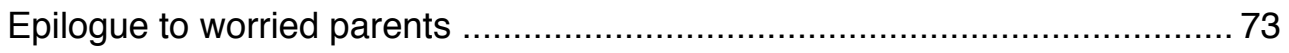

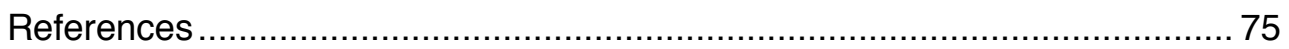

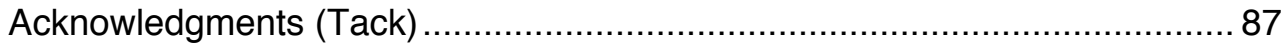

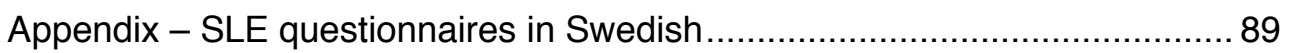




\section{List of Papers}

This thesis is based on the following original publications:

Nygren, M., Carstensen, C., Ludvigsson, J., Sepa Frostell, A. (2012). Adult attachment and parenting stress among parents of toddlers. Journal of Reproductive and Infant Psychology, 30, 289-302.

Nygren, M., Ludvigsson, J., Carstensen, C., Sepa Frostell, A. (2013). Family psychological stress early in life and development of type 1 diabetes: The ABIS prospective study. Diabetes Research and Clinical Practice, 100, 257-264.

Nygren, M., Carstensen, C., Koch, F., Ludvigsson, J., Frostell, A. (2015). Experience of a serious life event increases the risk for childhood type 1 diabetes: the ABIS population-based prospective cohort study. Diabetologia, 58, 1188-1197.

Nygren, M., Carstensen, C., Koch, F., Ludvigsson, J., Frostell, A. Serious life events across childhood and mental health problems in early adolescence: The moderating role of family climate. Results from the ABIS population-based longitudinal study. (Manuscript) 


\section{Abstract}

\section{Background}

It is still unknown why children develop type 1 diabetes (T1D), although both genetic predisposition and environmental factors seems to be involved. Stress has been suggested as one environmental factor contributing to the development of type 1 diabetes since the stress hormones may increase the need for insulin or increase insulin resistance. The family is important for the child's emotional security, development, and regulation of emotions, hence stress among the parent's may influence the child's experiences of stress and coping with stressors.

Aim

The aim of the current thesis was to evaluate self-assessment measurements of psychological stress in the family and to investigate if psychological stress in the family is involved in the development of childhood type 1 diabetes.

\section{Methods}

The All Babies in Southeast Sweden (ABIS) study is a prospective cohort study following children born in southeast Sweden between 1997 and 1999. All parents of children born in the region, approximately 21600 were asked to participate. In total, questionnaire data has been obtained from $n=16142$ (response rate approximately 75\%) in some of the six data-collections and between $15845(73 \%)$ and $4022(19 \%)$ at each data collection. Psychological stress in the family was measured by questionnaires assessing: Serious life events experienced by the child and the parent, parenting stress, parental dissatisfaction, parental worries, the parent's adult attachment, and the parents' social support. Identification of cases with T1D was done through the national register SweDiabKids. At Dec the $31^{\text {st }} 2012$ had in total $104(0,64 \%)$ children been diagnosed with type 1 diabetes. Diabetes-cases included in the study samples was $n=42$ and $n=58$.

\section{Results}

Parenting stress, parental worries, and size of social support were judged as reliable measurements assessing different aspects of psychological stress in the 
family, as well as they were all associated to children's mental health in early adolescence. A serious life event experienced in childhood (measured by checklist at age 5-6, 8 and 10-14 years) was associated with an increase in risk for manifest type 1 diabetes up to 13-15 years of age. None of the variables measuring psychological stress among parents were found to associate with risk of type 1 diabetes.

\section{Conclusions}

In addition to a checklist assessing serious life events experienced by the child is self-assessment measurements of parenting stress, parental worries and the parent's social support be useful in large-scale studies as proxies for psychological stress of the child. The current study is the first unbiased prospective study that can confirm an association between the experience of a serious life event and increased risk of T1D. The result was independent of the child's BMI and the parents' educational level. Our results gives us strong reason to believe that psychological stress caused by serious life events can play a part in the immunological process leading to the onset of type 1 diabetes. 


\section{Sammanfattning på svenska}

\section{Stress i barndomen och risken för typ 1 diabetes}

Varför barn utvecklar barndiabetes (typ 1 diabetes) är fortfarande okänt, men både gener och miljö verkar spelar roll. En miljöfaktor som skulle kunna ha betydelse är stress, eftersom stresshormoner kan påverka både känsligheten för, och behovet av, insulin. Tidigare har sambandet mellan stress och barndiabetes bara studerats $\mathrm{i}$ retrospektiva studier, där man efter att barnen insjuknat $\mathrm{i}$ diabetes frågat om deras stress-upplevelser innan diagnosen. Den här studien (Alla Barn i sydöstra Sverige; ABIS) är den första som undersöker sambandet i en prospektiv studie, d.v.s. vi har frågat om stress hos barnen och inom familjen innan några av dem har fått diabetesdiagnos.

ABIS följer barn födda i sydöstra Sverige mellan 1997-1999 och samlar in data genom frågeformulär om miljöfaktorer som kan spela roll för utvecklingen av barndiabetes. Totalt har föräldrar till drygt 16000 barn svarat på minst ett frågeformulär. Eftersom barnen är små så frågar vi om stress hos föräldrarna, samt om svåra livshändelser som barnet varit med om.

Resultaten visar att stress hos föräldrarna (stress i föräldrarollen, oro för barnet, föräldrarnas sociala stöd) under barndomen är kopplat till barnens psykiska hälsa i 12-14 års ålder. Vi ser det som ett argument för att stress hos föräldrarna påverkar barnens upplevelser av stress. Vi hittar däremot inget samband mellan stress hos föräldrarna och högre risk för barndiabetes, men vi kan inte heller utesluta att ett litet samband skulle kunna existera.

Resultaten visar däremot att de barn som upplevt en svår livshändelse under barndomen, ca $30 \%$ i vårt urval (och det är troligen en underskattning), har en större risk för att sedan insjukna i diabetes jämfört med de som inte upplevt en sådan händelse. Svåra livshändelser är händelser som t.ex. dödsfall och allvarlig sjukdom i familjen, skilsmässa/separation, konflikter mellan vuxna i hemmet, nya barn eller vuxna i familjen. De här resultaten ger oss anledning att tro att stress, till följd av en svår livshändelse, på något sätt påverkar den autoimmuna processen i kroppen som så småningom leder fram till en barndiabetes-diagnos. 
Men i tolkning av resultaten är det viktigt att komma ihåg att risken för att få barndiabetes fortfarande är mycket liten (bara 5 av 1000 barn i ABIS har barndiabetes vid 14 års ålder), och de allra flesta av oss upplever svåra livshändelser under barndomen utan att senare få diabetes. 


\section{Abbrevations}

ABIS All babies in southeast Sweden

BMI Body mass index (age adjusted according to international standard)

IA-2A Autoantibodies towards Tyrosine phosphatase

IAA Insulin autoantibodies

ICA Islet cells autoantibodies

ICC Intraclass correlation

GADA Glutamic acid decarboxylase autoantibodies

HR Hazard Ratio

HPA Hypothalamic-pituitary-adrenal (axis)

PAR Population attributable risk

RQ Research question

RSQ Relationship scale questionnaire

SDQ-S Strength and difficulties questionnaire, self-report version

SES Socioeconomic status

SLE Serious life event

SPSQ Swedish Parenthood Stress Questionnaire

T1D Type 1 Diabetes

T2D Type 2 Diabetes 


\section{Introduction}

\subsection{Background}

It is still unknown why children develop type 1 diabetes (T1D), although both genetic predisposition and environmental factors seems to be involved. T1D is one of the most common chronic diseases among children in our part of the world and the incidence has increased worldwide during the last half decade (Knip, 2012). The All Babies in Southeast Sweden (ABIS) study is a large prospective cohort study that was started in 1997 with the main aim to find environmental factors contributing to the development of T1D.

Stressful life events have for long been studied as possible factors influencing the development and onset of T1D (Johnson, 1980). As early as 1679 Willis believed that diabetes was the result of 'prolonged sorrow' (Johnson, 1980), and in the 1950th Hinkle observed that the onset of diabetes often co-occurred with stressful experiences (Hinkle Jr et al., 1951). Therefore, one question measuring the experience of serious life events was included from the start of the study. As the study went on, new researchers with competence in psychological stress were involved in the project, the measurements of stress were expanded and results from ABIS concerning stress started to be found. This progress is clearly visible in our measurement of serious life events (SLEs) where we in the ABISstudy started with one single question and at the latest data collection measure it by a checklist where the parent also report how stressful the specific event was (see Appendix for the questionnaire of SLE at each data collection).

The current thesis is a continuation of the work previously carried out in ABIS by Anneli Frostell (former Sepa) who examined the association between stress and diabetes-related autoantibodies early in life (Sepa, 2004), and by Felix Koch who examined the association between stress in childhood, obesity and cortisol (Koch, 2009). The current thesis that you have in your hand contains the first results from the ABIS-project with stress as the exposure and manifest T1D as the outcome. Because it was not until now, 13 to 15 years after the study started, the number of children who subsequently have been diagnosed with manifest T1D was large enough for initial statistical analyses with T1D as an outcome. 


\subsection{Stress}

\subsubsection{The concept of stress}

Stress is a word with many connotations. In everyday language, I often hear people use the term stress to express a time-pressure and an experience of too much to do. I believe this everyday interpretation may fit quite well within the psychological definitions of stress where stress is understood as the individual experience of the demands from the environment, although theories of psychological stress try to identify the mechanisms for the experiences of stress and go beyond simple 'not enough time' ideas of stress. There is no universal definition of stress, rather different traditions and evolvements. In this thesis, I will use concepts of stress originating both from biology/medicine (i.e. Selye 1956 and later McEwen \& Wingfield 2003) and social-/behavioural sciences (i.e. Lazarus and Folkman 1984).

\section{Allostatic load}

Acute stress, as the physiological response to an environmental demand activates the sympathetic division of the autonomic nervous system. Hormones (norepinephrine, epinephrine, cortisol) are released in order to preparing the body for fight or flight, and the immune system prepares for a possible skindamage (Dhabhar, 2009). McEwen defines this adaptive response to challenging conditions as an allostatic process, i.e. an adjustment process in order to maintain stability in the body through change that is mediated by the allostatic systems (nervous, endocrine and immune system) (Danese \& McEwen, 2012; McEwen \& Wingfield, 2003). This adaptive response to stress is positive in the short run by protecting the body during a challenge, but in the long run this stress response turns to be damaging. Chronic and/or repeated activation of the allostatic systems turns this adaptive response to maladaptive for health. McEwen defines this as allostatic load, which is understood as the accumulated pressure on the body from a prolonged period of physiological stress-response. Or in other words; the cumulative burden on the body from a longer time of a chronic stress-response (McEwen \& Wingfield, 2003; McEwen \& Wingfield, 2010). 


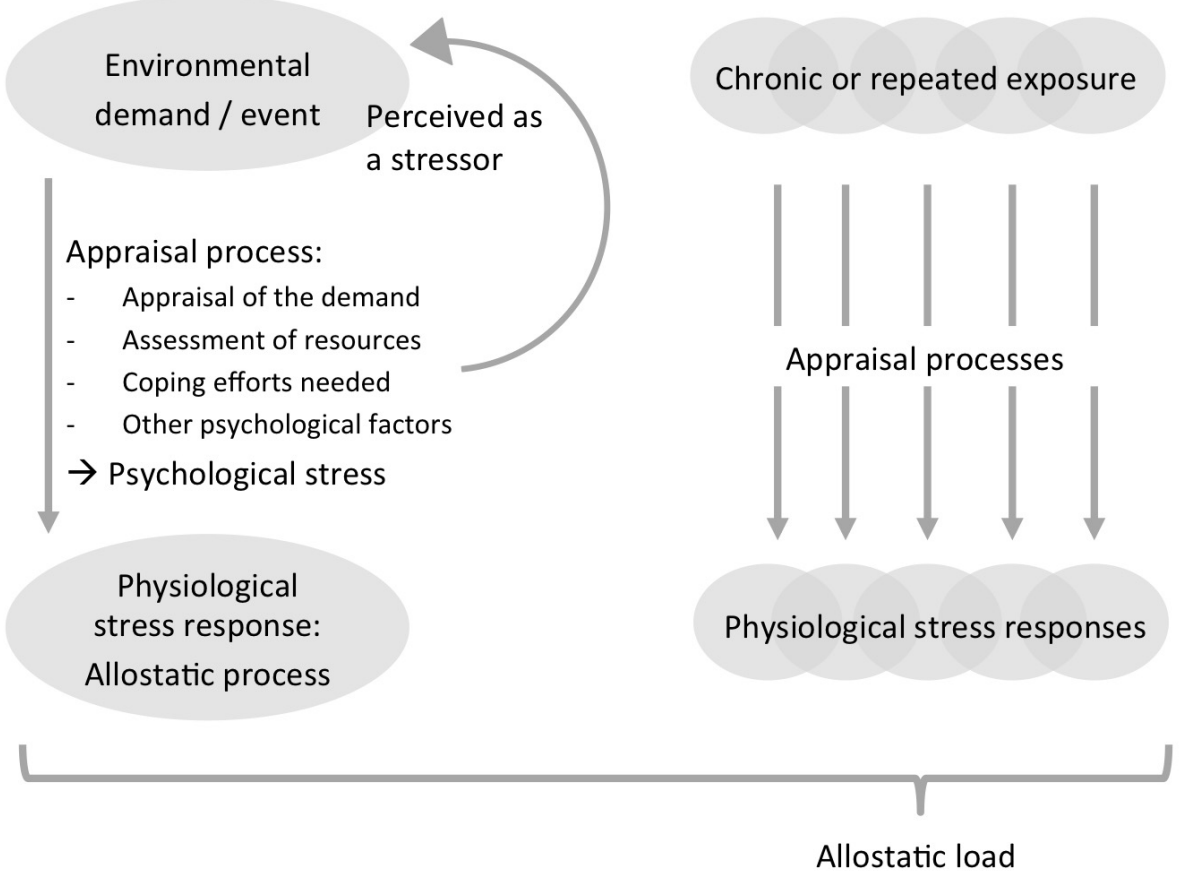

Figure 1. Theoretical model of stress.

Psychological stress

The individual physiological stress response are according to Lazarus and Folkman (1984) depending on the individual persons cognitive perception of the demands. They argue that the connection between environmental demands and the physiological stress-response is mediated by cognitive appraisal of the demand, assessment of the individual's resources, coping effort needed and other psychological factors - this is called the appraisal process. Psychological stress is defined as the experience of stress that occurs when an event is appraised as threatening or harmful and the individual perceive that she/he doesn't have enough resources to cope with the situation. The perception of the demand does not need to correspond with the actual magnitude of it: the perception can both suppress very stressful events and amplify minor events (Cohen et al., 1995; Monroe, 2008).

Adding Lazarus and Folkman's appraisal process with McEwens allostatic load gives a definition of stress (the negative chronic stress) as a chronic or repeated 
stress-responses due to environmental demands that the person perceives as stressful, see Figure 1.

\section{Stressors}

In most stress-research the environmental events or challenging conditions causing a stress response is referred to as stressors. Using Lazarus and Folkman's definition of stress, the event needs to be perceived as a stressor in order to be one. Demands or events that might be stressors for a child is for example biological needs (hunger, cold, pain), health events (infections, injuries), life events (starting school, death of a pet, new sibling, migration), relationship with caregivers (separation from caregiver, parental unresponsiveness). In this study, both unpredictable and predictable events or circumstance that can be perceived as stressful will be referred to as stressors. Furthermore, it is not necessary the stressor actually causes a stress-response in each person exposed to it; instead the stressor should be understood only as a potential stressor.

\subsubsection{Measuring stress}

In correspondence with the conceptualization of stress, there are three main traditional strategies of operationalize and measure stress: The biological, the environmental, and the psychological approach (Cohen et al., 1995).

\section{The biological approach}

In the biological approach, the measure has usually been cortisol as a marker of hypothalamic-pituitary-adrenal cortical (HPA) axis activation (a physiological stress-response). The major research focus when measuring cortisol has been the development and regulation of the HPA-axis, and the relationship between stressors, psychological stress, and HPA-axis activation (Monroe, 2008; TurnerCobb, 2005; Vanaelst et al., 2012). In the current study, this measuring approach will not be used; however it is relevant to mention this approach since I will refer to studies using it. The outcome in the current study is an immunological disease, and one possible mechanisms linking stress and T1D goes via hormones released during stress, not least cortisol. Although cortisol in saliva is a biological marker of an acute stress response and has been used for a while, it might be difficult to obtain good data: No standardized method exists (Monroe, 2008), and the natural daily variation is large (Gröschl et al., 2003). Cortisol in 
hair is a new method under investigation used to measure long term activation of HPA-axis (Karlén et al., 2015).

\section{The environmental approach}

The environmental approach measures stressors and were founded by Holmes and Rahe who developed a self-report checklist for measuring life changing events in adults (the Social Readjustment Rating Scale; Holmes \& Rahe, 1967). Since then a numerous of different checklists measuring life events have been developed and used, both including many different stressful events or few major traumatic events, or events that is stressful specific for children (e.g. Coddington 1972). The common basic assumption in this approach is that a specific event causes a similar stress-response in most people, which is a weakness of this method of measuring. Current research using the environmental approach often uses a cumulative approach adding the number of stressors together during an exposure period (e.g. Deater-Deckard et al., 1998; Flouri et al., 2010; Tiet et al., 1998; Vanaelst et al., 2012). The cumulative approach corresponds well with the theory of allostatic load as the cumulative physiological stress-response. However, there is a great variability between measurements of cumulative life events (Grant et al., 2004), and the inclusion of stressors differs between studies. While some strictly examine stressful life events (Grant et al., 2004), others have broadened the inclusion of stressors and include psychological and social adversities such as maltreatment, neglect, economic hardship, and low social status (e.g. Danese \& McEwen, 2012; Karlén et al., 2015; Kessler et al., 2010).

\section{The psychological approach}

The psychological approach is based on Lazarus theories of appraisal and measures the perception of stress and resources to cope. The most widely used general scale is the Perceived Stress Scale (Cohen et al., 1983; Monroe, 2008) measuring a nonspecific appraisal of stress. However, there exist a variety of scales that measure the perception of stress or coping in relation to different areas in life, such as parenting stress used in this study (Östberg et al., 1997). The psychological and environmental approaches have also been combined by Brown and Harris who developed a checklist where the participant report his/her individual experience as well as the importance of the events reported (Life Events and Difficulties Schedule; Brown \& Harris, 1978). 


\subsubsection{Psychological stress in children}

In this study, the primary interest was the child's experiences of stress and exposure to stressors that in turn may generate a physiological stress response. To understand children's experiences of stress it is crucial to know the context; the stress is experienced both within an environment, and because of an environmental demand. I use Bronfenbrenner's Ecological System Theory (Bronfenbrenner, 1979) in an attempt to understand and structure the environment where the child lives, and the relations with the family and the social structure/community.

According to Bronfenbrenner the world of the child consists of five systems that are dynamic and interactive (Bronfenbrenner, 1979; Swick \& Williams, 2006): (1) The microsystem contains the systems with which the child has direct contact, such as family system and school system, and the binary relations between the child and each system. (2) The mesosystem, is the relation between two or more systems in which child, parent and family lives. It's about being in relation with each other in triads or more. For example, the connection between the child's pre-school and his/hers parents. (3) The exosystem is the larger social system that the child experience indirectly, through an interaction with some structure/part in the child's microsystem. For example the parents' workplace, family social networks, and neighbourhood community contexts. (4) The macrosystem is the larger institutional systems of a culture such as the economic, social, education, legal, and political systems that forms an overall system of cultural beliefs and societal values that influence what, how, when and where we carry out our relations. (5) The chronosystem is the historical context in the different systems. For example, the parent-child relationship may be more influenced by the family-history of relationships then by concurrent dynamics.

\section{The family}

The family is the child's most important microsystem early in life for learning how to live. It is in the family context that the child develops, in interaction with the other family members and their own personal characteristics (Rosa \& Tudge, 2013). For example, the parents (caregivers) attachment behaviours offers the child its first experience of trust in a close relationships. According to the attachment theory, early childhood is a sensitive period when attachmentpatterns are formed and the child learns how to regulate his/her emotions. In the 
parent-child interaction in infancy, the child seeks closeness when alarmed (worried or experiencing a sudden sense of danger) and a secure caregiver gives protection and emotional support through a sensitive and responsive parenting (Bowlby, 1969). If the parent-child relation is burdened by insecure attachment, low caregiving quality and/or insensitivity of the parent, the child is more likely to be sensitive to stressful events and unable to cope with potential stressors in a functional way. Several authors argue that the HPA axis is adjusted early in life through the parent-child interaction in response to stressors (Essex et al., 2002; Taylor et al., 2004; Turner-Cobb, 2005).

The family continues to be an important microsystem throughout childhood for the child's emotional security, development, and regulation of emotions. Concurrent associations between family environmental factors (such as family climate, family functioning, parent-child relationship) and child and adolescence mental health are well established (Låftman \& Östberg, 2006; Tiet et al., 1998; Vanaelst et al., 2012), as well as evidence for an mediating role for family relationships in the relation between stressors and child and adolescence psychopathology (Grant et al., 2006). Psychological stress among parents has also been related to concurrent physiological stress-response in terms of elevated levels of cortisol (Carlsson et al., 2014; Koch et al., 2010).

In this thesis, the focus will be on the family as the context where the child experience stress. The child's experiences of serious life events (stressors) and the parents perception of stress connected to parenthood (this is a part of the microsystem because the perceptions of stress is directly related to the child) will be examined as sources of stressors for the child. Also the supportive function of the family-system will be examined; if the parents' perception of stress has an impact on child mental health after experiences of serious life events.

The parents' experiences outside the family may also be relevant for the child's experience of stress, indirectly as exosystems. These experiences can be either empowering (e.g. adequate social support for the parents benefits the entire family) or degrading (e.g. stress at work impacts the entire family). In the current thesis, the parents' social support will be examined as a factor that may indirectly influence the child's experience of stress. The parents' social support have previously been shown important in protecting from high levels of 
parenting stress (Östberg et al., 2007).

\section{Social structure}

Low social status, economic hardship/poverty, low educational level, and other indicators of social adversity have for long been examined as stressors (Bradley \& Corwyn, 2002; Grant et al., 2003; Kessler, 1979). Exposure during childhood have in some studies been linked to increased levels of cortisol and dysregulation of the stress-responses (Evans \& Kim, 2007; Gustafsson et al., 2010; Karlén et al., 2015) but the evidence is weak (Dowd et al., 2009). It has been argued that stress in childhood mediates much of the relation between socioeconomic status (SES) and mental health as well as other health outcomes, where families from low SES-groups are more likely to experience stressful events, and perceive more stress connected to unemployment and economic hardship (Bradley \& Corwyn, 2002; Grant et al., 2003). The research-focus in this thesis is stress in terms of life events as stressors, and psychological stress among the parents and in the family, but I omit social and structural factors (i.e. SES) as stressors. It does not mean that social factors are irrelevant as stressors in relation to diabetes risk, only that it is outside the scope of this thesis. The reason is that social factors can also be seen as confounding factors, since they might affect health and health behaviour that in turn can affect the diabetes risk in other ways besides being a stressor. Hence, social factors (educational level, work-status) will in this thesis be used to control for, with the result that any association between stress and T1D or child mental health found is not caused by differences in these social factors.

\section{Gendered experiences}

Gender/sex is a both a biological and social category that highly influences our experiences in life, how other regards us and how we view ourselves. For example are the cultural believes and expectations of motherhood not the same as those of fatherhood. Regarding the experience of stress, sex/gender may influence both what kind of environmental demands we faces, and our cognitive appraisal of the demand, our assessment of resources to cope, coping strategies, and so on. The perception of stress, of course, varies greatly between individuals, but differences between the group of men and group of women have been observed. Women report using more of some types of emotional regulation strategies, both adaptive and maladaptive (Nolen-Hoeksema, 2012) and stressrelated disorders such as depression and anxiety are more prevalent among 
women (Kessler et al., 1993; Nolen-Hoeksema, 1987). Girls and young women report higher levels of poor mental health (anxiety and depressive symptoms) than boys and young men (Lundh et al., 2008; Nolen-Hoeksema, 2012). Most of the differences have been found in the perception of stress, however some differences have been observed regarding life events where women reporter more experiences of events related to interpersonal relations (Dalgard et al., 2006; Kendler et al., 2001). Hence, sex/gender may be relevant both regarding the parents' experiences of stress, the parents' perceptions of their child, and the child's experiences of stress.

As suggested by Springer, I use the term 'sex/gender' since the biologically defined 'sex', and socially constructed 'gender' are highly entangled and inseparable in health research (Springer et al., 2012). In order to not be a genderblind study, I included sex/gender of the parent as a factor to stratify by (Paper 1), and sex/gender of the child to adjust associations for (Papers 4) and test interactions for (Paper 3), although sex/gender not are included in the main aim. Sex/gender of the parent was not adjusted for as a possible confounding factor in the analyses because I wanted to include the gender-specific stress associated with parenthood in the measure of stress.

\subsection{Type 1 diabetes}

\subsubsection{An autoimmune disease}

T1D is a chronic disease, which is usually preceded by an autoimmune destruction of the insulin-producing beta-cells in pancreas in genetically susceptible individuals. In newly diagnosed children, high levels of autoantibodies towards insulin (IAA), islet cells (ICA), tyrosine phosphatase (IA-2A) and glutamic acid decarboxylase (GADA) have been observed. But why the immune system is acting towards the body's own beta-cells is still unknown (Atkinson et al., 2014; Williams \& Pickup, 2004). There is clear evidence that certain genetic predisposition is important for the development, although far from all individuals with genetic susceptibility develop the disease which implies that environmental factors also are involved (Knip et al., 2005).

In Figure 2, the suggested developmental process of T1D from birth to onset has been modelled (Atkinson et al., 2014; Knip et al., 2005). Beta-cell autoimmunity 
is suggested to start early in childhood in genetically predisposed individuals, triggered by an environmental factor. The beta-cell loss continues trough childhood, with relapsing or remitting patterns, where environmental factors may both drive and modify the process. At last, the remaining beta-cells cannot produce sufficient amount of insulin needed, and clinical onset of diabetes occurs. Several environmental factors have been proposed to contribute to the developmental process of T1D, such as viral infections, dietary factors in early childhood, lack of vitamin D, birth weight and early weight gain, as well as chronic stress (Cardwell et al., 2010; Knip et al., 2005; Knip et al., 2010; Ludvigsson, 2006; Tauriainen et al., 2011). Furthermore, physiological events such as immune system development may contribute to the process.

T1D is one of the most common chronic diseases among children in our part of the world. The incidence has increased worldwide during the last half decade, but the difference in incidence between countries is huge (Knip, 2012; Patterson et al., 2014). In Finland, the largest increase has been observed in the age group below 5 years of age (Harjutsalo et al., 2008). In Sweden, the incidence rate has been estimated to $43 / 100000$ and the prevalence in 2013 to $4.2 / 1000$ among children up to 14 years of age (Patterson et al., 2014). Diabetes onset is most common during puberty, with an incidence of $>50 / 100000$ among children aged 10-14 in Sweden (Rawshani et al., 2014).

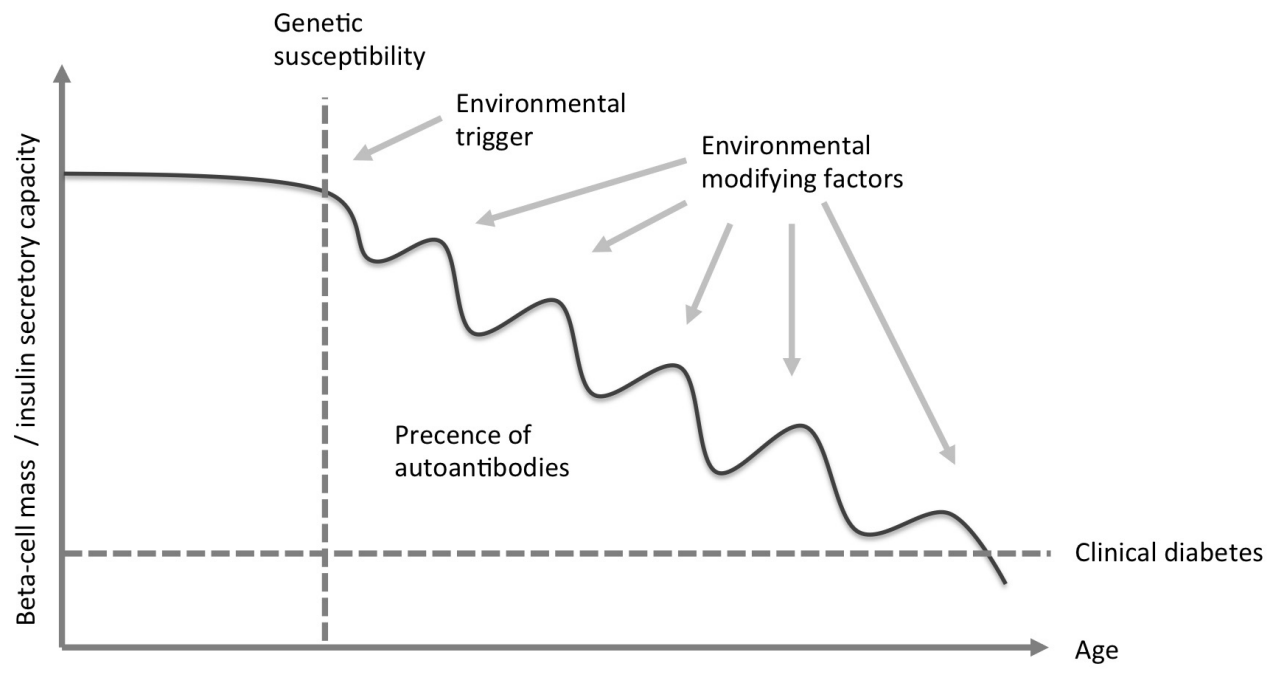

Figure 2. Model of the autoimmune process before clinical onset of manifest T1D (Atkinson et al., 2014; Knip et al., 2005). 


\subsubsection{Hypothesis linking stress to T1D}

Stress has been suggested as one environmental factor contributing to the development of the disease (Ludvigsson, 2006). Theoretically, stress could trigger the start of the autoimmune process, contribute to its progression, and/or put it over the tipping point to clinical diagnosis.

Chronic psychosocial stress has been linked to dys-regulation of the circadian cortisol rhythm, both to higher concentrations of cortisol as well to a downregulation and/or a smoothing of the daily variation. In children have elevated levels of cortisol been associated cross-sectionally to psychosocial stress (Carlsson et al., 2014; Gustafsson et al., 2006), as well as longitudinally to parenting stress early in the child's life (Essex et al., 2002; Koch et al., 2010).

To put it simple, cortisol reduces the effect of insulin and hence chronic stress that results in elevated cortisol levels may contribute to insulin resistance. Epinephrine (another hormone released during stress), in turn, inhibits the insulin secretion and leads to an increase in the need for insulin. According to the beta-cell stress hypothesis (Ludvigsson, 2006), all factors that increase the need for insulin or increase insulin resistance may be regarded as risk factors for development of T1D, since they place added stress/burden on the insulinproducing beta-cells. So far, some evidence has been found on the immunological level where high psychological stress among children has been associated to low levels of c-peptide (released together with insulin), indicating exhausted beta-cells (Carlsson et al., 2014).

Chronic psychological stress has been shown to both suppress the immune response and contribute to an imbalance in the immune system (Carlsson et al., 2014; Dhabhar, 2008; Segerstrom \& Miller, 2004). Hence, an alternative mechanism linking stress to the development of T1D may be via a more general imbalance in the immune system, which in turn could induce an immunological reaction against the beta-cells in genetically predisposed individuals. Exposures to stressors in childhood have been linked to increased risk for both autoimmune diseases as well as other common diseases both in childhood and in adult life (Danese \& McEwen, 2012; Dube et al., 2009; Karlén et al., 2015). 


\subsubsection{Previous empirical findings}

Previous research on the associations between psychological stress in childhood and onset of T1D is not coherent. All of the former studies (that I know about) have been retrospective case-control studies or on an ecological level. Most of them have investigated stress as a contributor to the onset of manifest T1D, and consequently most evidence has been found concerning stress experienced the year before onset.

\section{Stress early in childhood}

Only two retrospective studies have explored stressful experiences early in childhood; one found support for an increased risk for T1D associated with negative life events occurring during the first two years of life (Thernlund et al., 1995), the other study failed to find such support for stressful events experienced during fetal life and the first 2 year of life (Karavanaki et al., 2008). Previous studies in ABIS have examined the association between stress early in life and diabetes-related autoantibodies. Associations were found between single autoantibody positivity and parenting stress and SLEs experienced during the first year of life, and mother's experience of divorce during the first 2-3 years of the child's life, but not for any kind of SLE experienced by the mother during the first 2-3 years of the child's life (Sepa et al., 2005; Sepa et al., 2004). However, it was later shown that less then $5 \%$ of those with single autoantibody positivity develop T1D (Atkinson et al., 2014).

\section{Stress during the entire childhood}

Support for any kind of experience of a negative life event during the entire childhood to be of importance for the diagnose of T1D has been found only if the event was judged as negative for the child (Thernlund et al., 1995), but not for the experience as such (Thernlund et al., 1995; Vialettes et al., 1989), nor the number of events experienced (Karavanaki et al., 2008). Some support has been found for specific types of events including parental loss due to divorce/separation or death (Karavanaki et al., 2008; Leaverton et al., 1980; Stein \& Charles, 1971), and parental dispute (Karavanaki et al., 2008).

Stress the years(s) before onset

An association between T1D and an overall experience of stressful life events the year(s) prior diagnosis has been found both for at least one experience of stressful events (Karavanaki et al., 2008; Siemiatycki et al., 1989; Sipetić et al., 
2007; Vialettes et al., 1989) and for the frequency of events experienced (Siemiatycki et al., 1989; Sipetić et al., 2007; Vlajinac et al., 2006). Other studies though, have failed to find associations with experience of life events the year before diagnosis (Hägglöf et al., 1991; Littorin et al., 2001; Thernlund et al., 1995) except for specific types of events such as threat of or actual loss within the family (Hägglöf et al., 1991), serious illness/injury or hospitalization (Littorin et al., 2001), and trauma of war among boys (Zung et al., 2012). Furthermore, a chaotic family function has been associated to T1D, but not lack of parental social support (Thernlund et al., 1995).

Child mental health problems the year prior to diagnosis have also been associated with T1D; both overall problems (Siemiatycki et al., 1989; Sipetić et al., 2007; Thernlund et al., 1995) and specific problems such as inhibition and acting-out (Thernlund et al., 1995), learning problems (Sipetić et al., 2007; Vlajinac et al., 2006), problems with friendship (Sipetić et al., 2007), as well as sleeping problems and nightmares (Siemiatycki et al., 1989). 


\subsection{Aims and research questions}

The overall aims of the thesis was to

(a) evaluate different self-assessment measurements, filled out by the parents, of psychological stress in the family over time

(b) investigate if psychological stress in the family, during childhood, is involved in the development of type 1 diabetes

The specific research questions (RQ) were:

1. How are different dimensions of psychological stress among parents interrelated? Are they all relevant for measuring psychological stress in the family? (Paper 1 and frame-work of the thesis)

2. Does psychological stress among the parents associate to the child's mental health in early adolescence? Can it be used as a proxy for the level of psychological stress of the child? (Paper 4)

3. Are the child's experiences of serious life events in childhood associated with a higher risk of manifest type 1 diabetes? (Papers 2 and 3 )

4. Are psychological stress among parents' associated with higher risk of manifest type 1 diabetes for the child? (Papers 2 and 3 )

5. Is the timing of stress relevant for the risk of type 1 diabetes? Is stress more important during infancy, toddler/preschool age, or early school age? (Papers 2 and 3) 


\section{Methods}

\subsection{Study design}

\subsubsection{Population}

The All Babies in Southeast Sweden (ABIS) study is a prospective cohort study following children born in southeast Sweden (The counties of Östergötland, Jönköping, Kronoberg, Kalmar, and Blekinge) between October $1^{\text {st }} 1997$ and September $30^{\text {th }} 1999$ with the main aim to find risk factors for T1D. All parents of children born in the region, approximately 21600 , were asked to participate. Both questionnaire data from parents and children, and biological samples have been collected. In the current thesis, questionnaire data were used in all four studies and blood samples in Paper 2.

\subsubsection{Data collection}

Questionnaires and biological data have so far been collected at six time-points, see Figure 3. At birth, the questionnaire was given to the mothers when leaving the maternity ward. The mother either returned it immediately or at the first check-up at the well baby clinic at one week of age. The data collections at age 1, age 2.5-3, and age 5-6 were done in connection to the regular check-ups at the well baby clinics. Capillary blood was drawn from the child at the clinic at age 1 and 2.5-3, and venous blood at age 5-6. The questionnaires were filled out during the visit at the clinic or later at home and no reminders were used. In total, 250 well baby clinics were involved in administrating the questionnaires. Around $99 \%$ of all Swedish parents bring their children to these check ups, which are government subsidized.

At age 8 two questionnaires - one to the parent and one to the child - were sent home to the family and returned in pre-stamped envelopes via mail. The parents were also asked to take their child to a health care centre for a blood sample. At age 10-14 the follow-up was first conducted in collaboration with the schools in the region where entire classes of children born 1997-1999 were asked to answer a questionnaire at school and bring a questionnaire home to one parent whom 


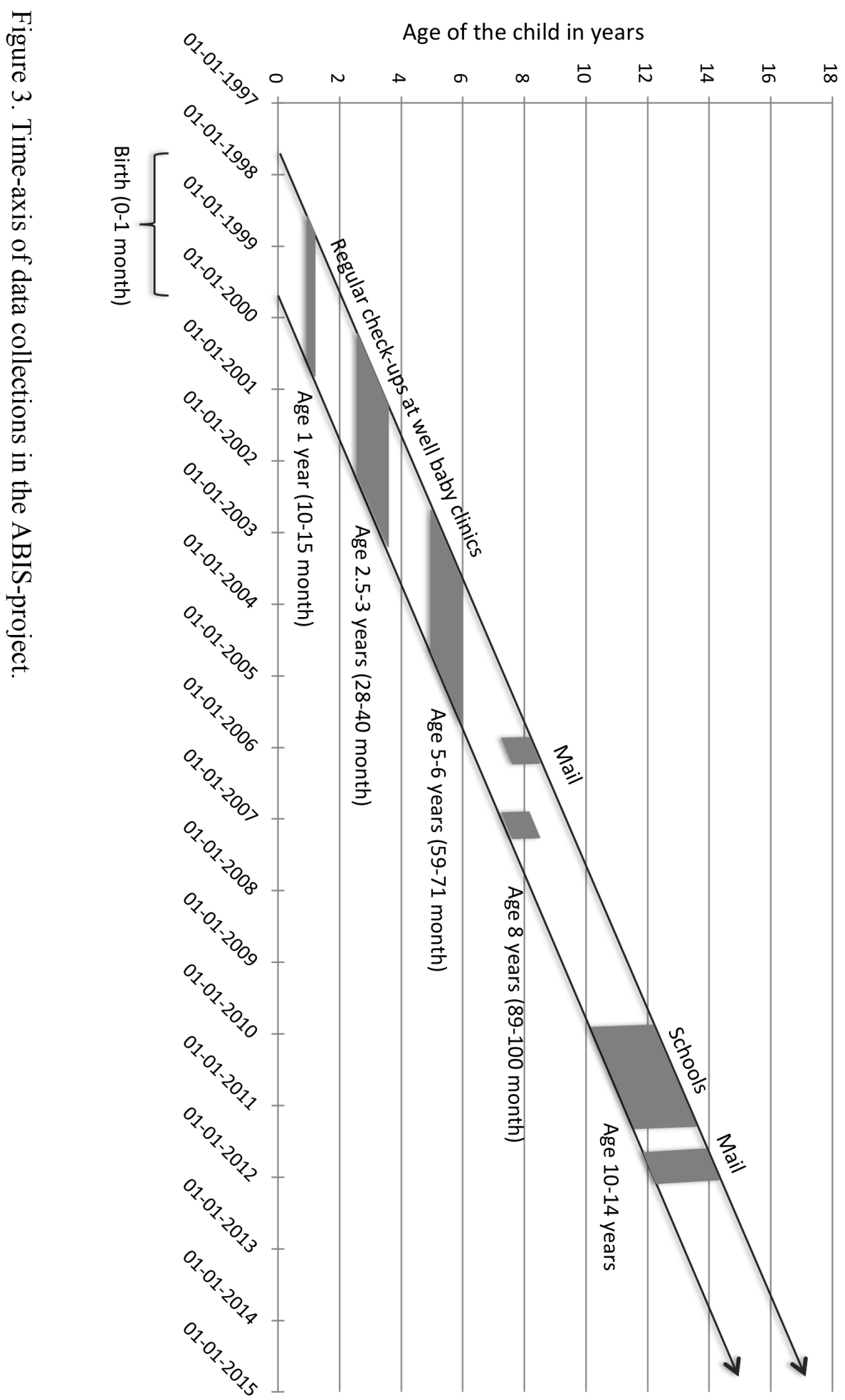


returned it by mail. Unfortunately, the response-rate using this method was low, therefore questionnaires to the child and one parent were sent home by mail to a sub-sample of 8000 of the 13145 children in the ABIS-cohort who had not already participated via schools. This subsample of 8000 consisted of two parts: (1) $n=4969$ was a selected sample from the ABIS-cohort with children who participated at 4 or 5 of the previous data collections and/or had ISO-BMI $\geq 30$ sometimes previously during the study; (2) $n=3031$ was a random sample from the rest of the ABIS-cohort $(\mathrm{n}=8032)$ not already selected. The questionnaires were returned by mail and one reminder was sent out four weeks after the questionnaires. No blood-samples were collected in association with the 10-14 year data collection.

\subsubsection{Participation rate}

In total, questionnaire data has been obtained from $n=16142$ (response rate approximately $75 \%$ ) in one or more of the six data-collections. However, the response rate declines with time as illustrated in Figure 4 and only $n=1666(8 \%)$ participates in all six data collections. At age 10-14 the questionnaires were not distributed to the entire ABIS-cohort, hence that response rate is more complicated to calculate. In the first phase through the schools the response-rate on individual level is unknown since we do not know how many children/parents who actually got the questionnaire. At school-level, the participation rate was $31 \%$ (198 schools of 630 in the region), resulting in 1648 responses from parents and 2044 responses from children where the parent either participated or gave clear consent by mail later. In the second phase through mail, the response rate was $31 \%$ resulting in $n=2391$ answers whereof 2366 from parents and 2166 from children.

At birth the mother filled out the questionnaire, but at the later time-points no instruction was given concerning whom of the parents that should answer the questionnaire. Usually, the parent-questionnaire was filled out by the mother (age $194.6 \%$, age 2.5-3 96.6\%, age 5-6 91.1\%, age $889.0 \%$, and age 10-13 $84.8 \%$ by only mothers, $6.6 \%$ by mothers and fathers together, and $7.4 \%$ by only fathers). 


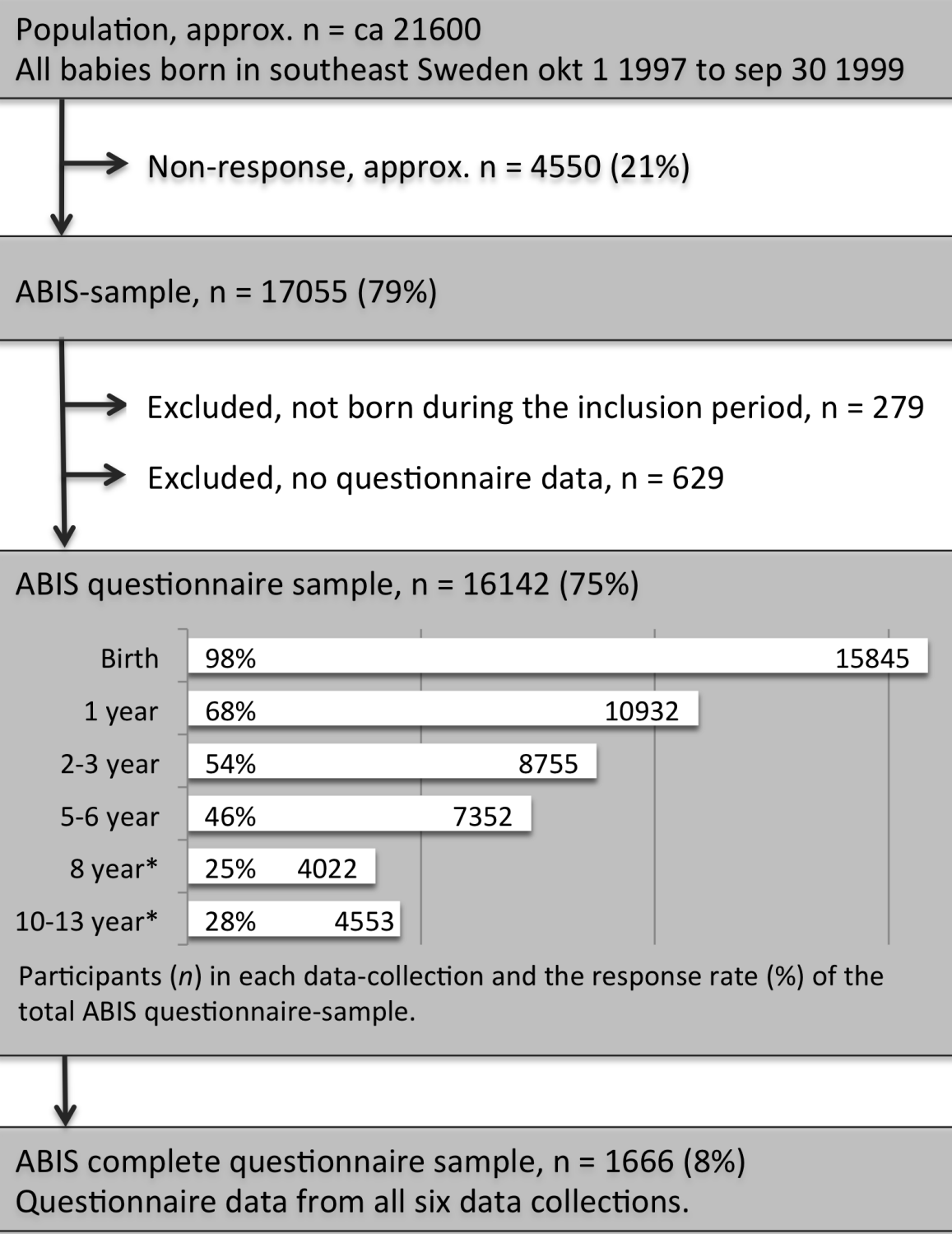

Figure 4. Flow diagram of ABIS-sample.

* A parent and/or the child have answered the questionnaire. 


\subsubsection{Descriptive statistics of the ABIS-sample}

Of the children included in the ABIS questionnaire sample 51.8\% ( $\mathrm{n}=8361)$ were boys and $48.2 \%(n=7781)$ girls. In the sample are $2.3 \%(n=376$, i.e. 163 pairs) twins and $1.9 \%(\mathrm{n}=308$, i.e. 154 pairs) siblings, for those cases the parents participates more then once since the child is the study object. First borns (without a sibling when born) were $37.9 \%(n=5974)$ of the sample. Mean age of the parents when the child was born were 29.6 (SD 4.6) years for the mothers and 32.1 (SD 5.4) years for the fathers, the median year of birth was 1969 ( $\mathrm{min}$ 1950, $\max 1983$ ) for the mothers and 1967 ( $\min 1932, \max 1982$ ) for the fathers. The proportion of mothers who were born outside of Sweden was $6.6 \%$ $(\mathrm{n}=1046)$ and fathers $7.2 \%(\mathrm{n}=1132)$. In total, 7.7\% $(\mathrm{n}=1212)$ of the ABISchildren had one of two parents born outside of Sweden and 3.1\% $(n=483)$ had parents who both were born outside of Sweden. The parents' educational level at birth are reported in Table 1.

Compared to the total population in Sweden in 1999, the proportion of parents born abroad are smaller in the ABIS-sample (11\% in Sweden), but the educational level are representative of Sweden (Sepa et al., 2004).

Table 1. The parents' educational level at birth.

\begin{tabular}{l|rc|rc|}
\hline \multirow{2}{*}{} & \multicolumn{2}{|c|}{ Mothers } & \multicolumn{2}{|c|}{ Fathers } \\
& $\mathrm{n}$ & $\%$ & $\mathrm{n}$ & $\%$ \\
\hline Compulsory school (9 years) & 1361 & $9 \%$ & 2122 & $14 \%$ \\
Secondary school (10-12 years) & 9411 & $60 \%$ & 9604 & $62 \%$ \\
University 1-3 years & 3046 & $19 \%$ & 1898 & $12 \%$ \\
University >3 years & 1950 & $12 \%$ & 1909 & $12 \%$ \\
\hline Total n & 15768 & $100 \%$ & 15533 & $100 \%$ \\
Missing & 374 & & 609 & \\
\hline
\end{tabular}




\subsubsection{Samples in Papers 1-4}

Paper 1 included all parents participating at age 2-3 that answered RSQ, $\mathrm{n}=8122$. Some of the participants included may be parents to children born outside the inclusion period, since no exclusion was done regarding time of birth of the child.

Paper 2 included participants answering the questionnaires at birth and age 1, $\mathrm{n}=8921$. Also here, participants born outside the inclusion period were not excluded.

Paper 3 included participants answering the questionnaire/s in one or more of the data collections at age $2.5-3,5-6,8$, and $10-14$ years, $n=10495$.

Paper 4 included participants answering the child-questionnaire at age 10-14 and the parent questionnaires at age 5-6, 8 and 10-14, $\mathrm{n}=1132$.

See Figure 5 for illustration of the four study-samples.

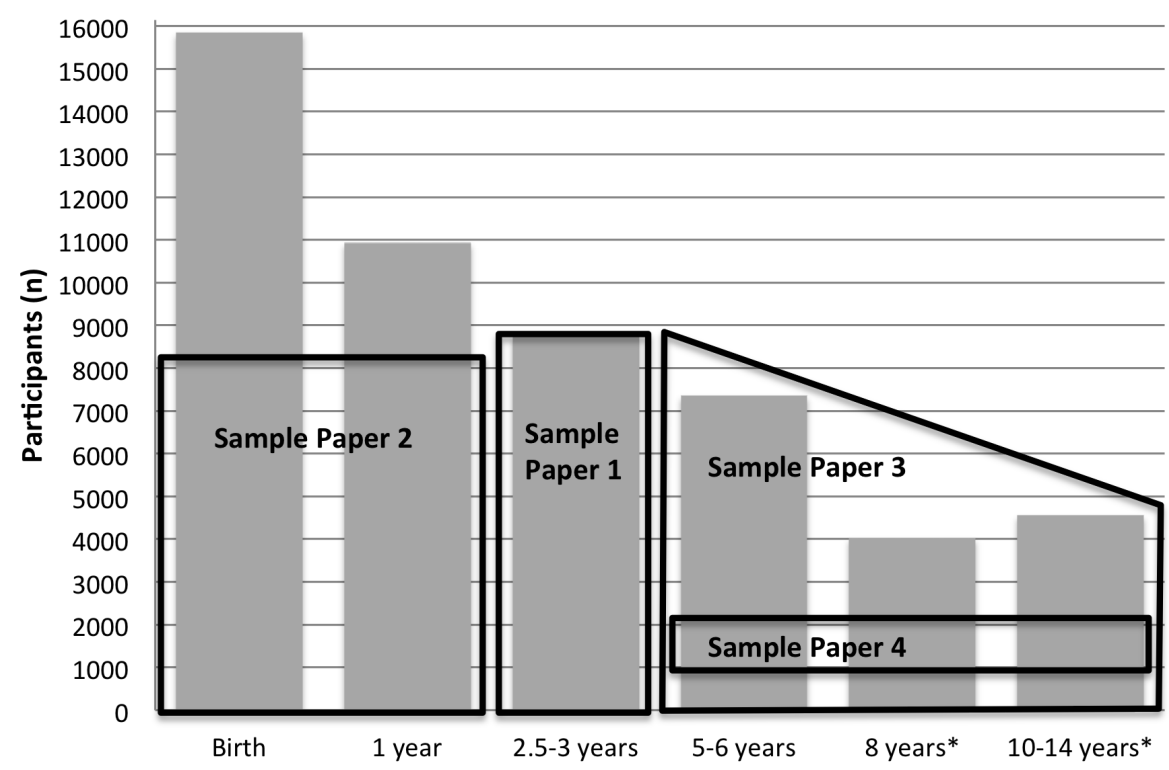

Figure 5. Study-samples in the four papers.

* A parent and/or the child have answered the questionnaire. 


\subsection{Ethical considerations}

The ABIS-study was approved by the research ethics committees of the Faculty of Health Science at Linköping University and of the Medical Faculty at Lund University, both in Sweden. Parents received written and oral information and were offered to see a video film about the ABIS-project before giving their consent to participate. Completing questionnaires and leaving biological samples have been considered as continued consent, except at the datacollection at age 10-14, through the schools, where the parents, who had not answered the parent questionnaire, were asked about consent for their child's participation through mail afterwards. Previously, results from ABIS have shown that the great majority of the parents felt calm about participating in the study (Ludvigsson et al., 2001).

\subsection{Measurements}

The focus in this study was psychological stress in the family as a stressor and/or coping resource for the child as a potential source for or protection from allostatic load (i.e. damaging stress), hence the perspective mainly correspond to the psychological approach by measuring the appraisal of stress among family members. Unfortunately, we could only ask about the parents' perceptions as long as the child was to small to answer self-report questionnaires itself. Besides asking for appraisals of stress, we believe serious life events in the family are important for the child's stress-response, hence we also uses parts of the environmental approach. The intention was to get a wide range of measures of stress in the family by asking about the participants' perception of stress, and about events that we (as researchers) define as potential stressors. Due to the prospective study design and a rare disease (T1D), the sample size had to be large; hence stress was measured by self-report questionnaires. See Table 2 for an overview of the measurements of psychological stress in the family used in each paper in the current thesis.

\subsubsection{Diabetes cases}

Identification of cases with T1D was done through the national register SweDiabKids that is a quality register in Sweden where all children in Sweden 
up to age 18 diagnosed with diabetes according to the international criteria are supposed to be registred. In 2008 the reported coverage of new cases were $99 \%$.

In Paper 2 the cases with T1D were obtained on 22 March 2011, in total 75 $(0,46 \%)$ ABIS-children had been diagnosed, whereof $n=42$ were included in the study-sample and diagnosed after the data collection at 1 year. In Paper 3 the cases were obtained at 31 December 2012, in total $104(0,64 \%)$ had been diagnosed whereof $n=58$ were included in the study sample and diagnosed after the data collection at age 2-3 years.

\subsubsection{Serious life events}

Both the child's and the parent's experiences of serious life events (SLEs) across childhood were measured with separate questions in the questionnaires. At birth and age 1, SLEs were assessed only by one question, at age 2 and onward the question was complemented by a checklist inspired by Holmes and Rahe (1967) and Coddington (1972). The questions at each data collection are presented in Table 3 and the items in the checklist are reported in Table 1 in Paper 3. Events experienced by the child are seen as stressors for the child, and events experienced by the parent as stressors for the parent and hence a proxy for stress in the family. However, many events are experienced both by the child and the parent, as for example death/illness/accident in the family, or divorce/separation for the parent resulting in single custody for the child.

\subsubsection{Psychological stress among parents}

The perception of stress among the parents in domains associated with parenthood was measured as proxies for the level of stress in the family that may have an influence on the child. Cronbach's alphas in the ABIS-sample, as an indicator of reliability, are reported in Table 5.

Parenting stress captures the parents' appraisal of stress in relation to parenthood and was assessed when the children were 1, 2-3, 5-6 and 8 years of age by the Swedish Parenthood Stress Questionnaire (SPSQ; Östberg et al., 1997), which is a translation and reconstruction of the Parent Domain of Parenting Stress Index (Abidin, 1990). SPSQ measures psychological stress due to parenthood in five sub-scales: Incompetence (e.g. 'It's more difficult than 


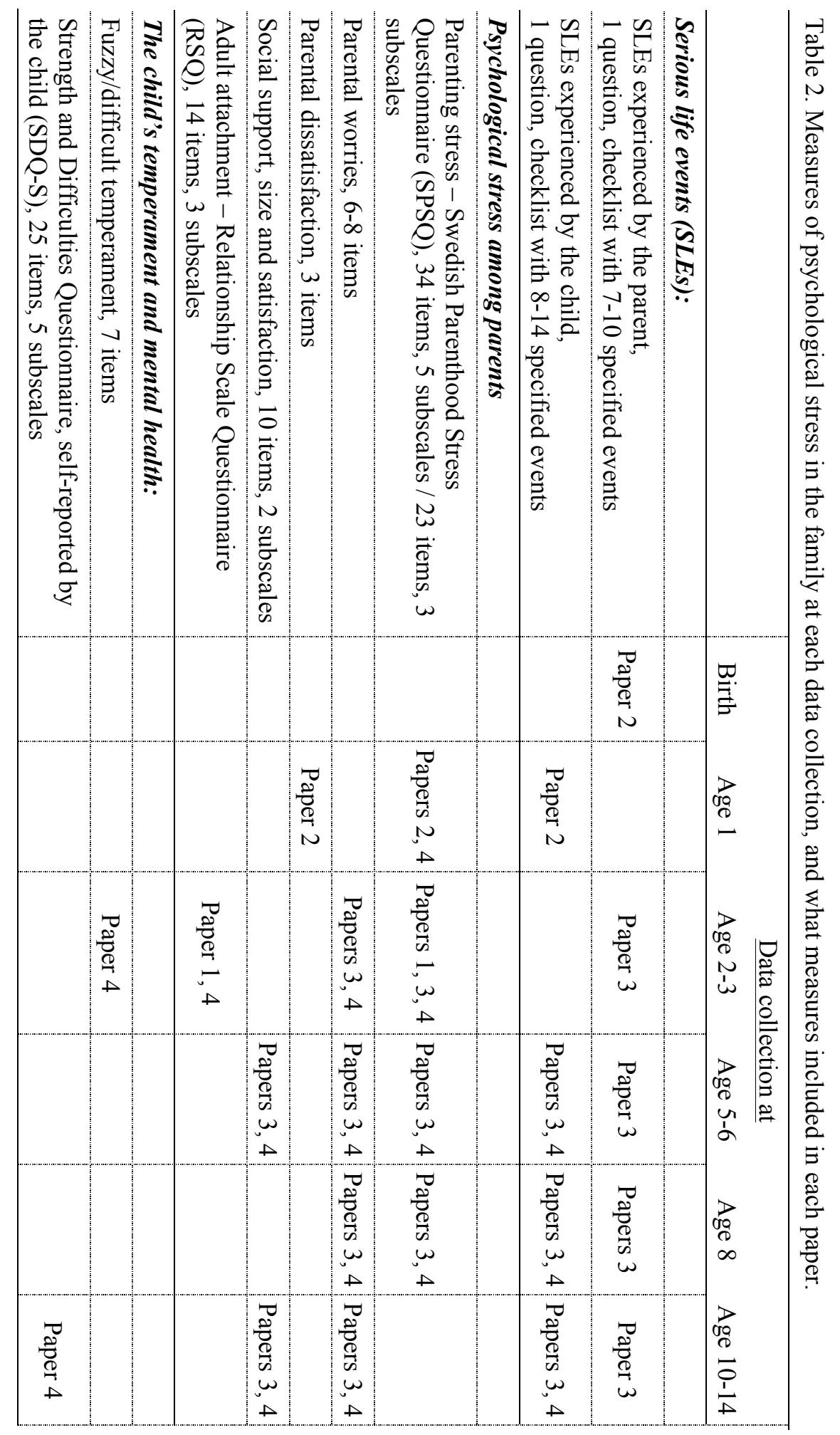




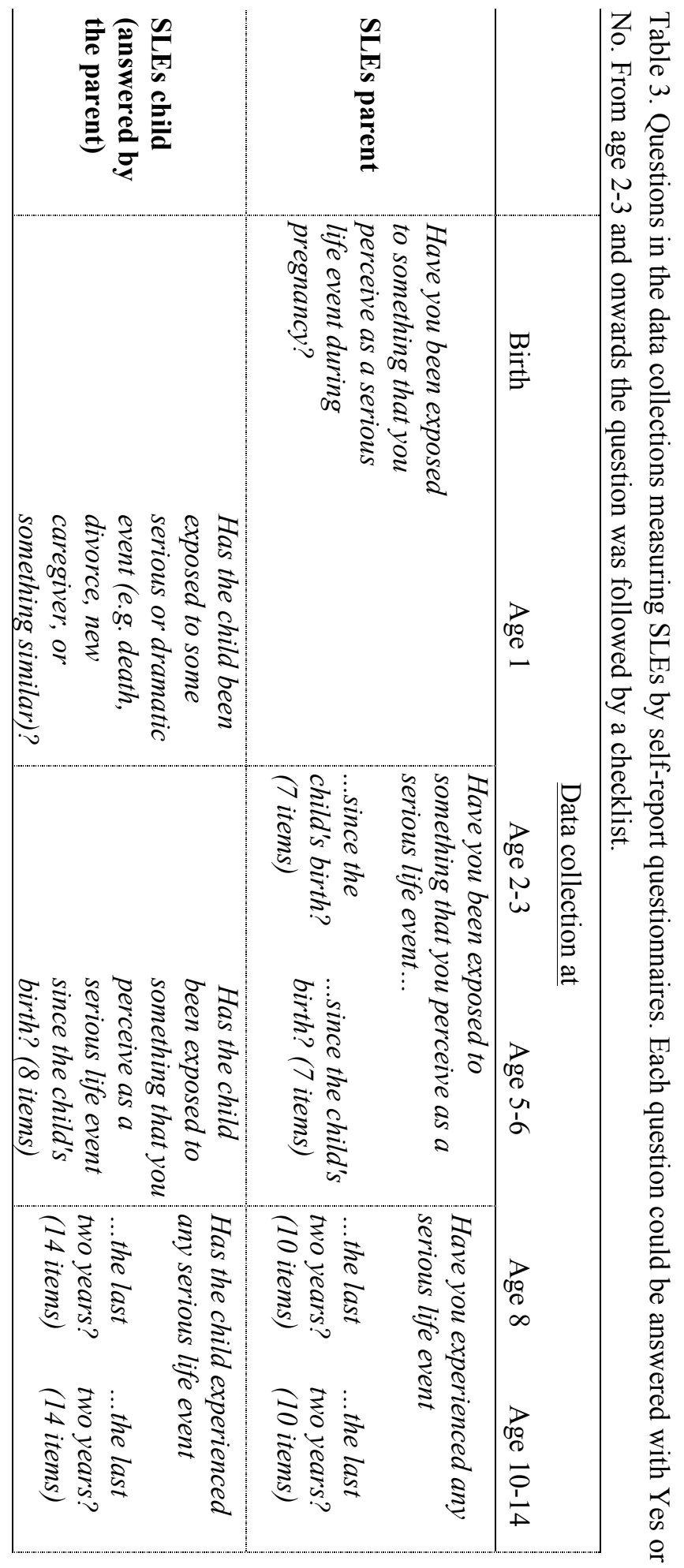


I expected to be a parent '), Spouse relationships problems (e.g. 'After I became a parent, I get less support than I expected from my spouse'), Role restriction (e.g. 'Since I had children I can hardly ever do the things that I personally like'), Social isolation (e.g. 'I feel lonely and without friends'), and Health problems (e.g. 'Due to changed sleeping-pattern, I often feel tired and out of shape'). At age 1 and 2-3 all five sub-scales with in total 34 items were included. At age 5-6 and 8 years only three sub-scales (Incompetence, Spouse relationship problems, Role restriction) with in total 23 items were included due to space restrictions. Each item was answered on a 6-point Likert scale from 'not true at all' to 'very much true' where a higher value indicates more stress. At each time-point, the level of total parenting stress was calculated by the mean of all answered items ( 5 unanswered items allowed). In Papers 3 and 4 the 23 items included at all four data collections were used in order to have comparable values over time. SPSQ is an instrument validated for Swedish conditions among mothers of young children, where it showed good test-retest correlation over 30 days ( $\mathrm{r}=$ 0.89 , and $0.86 \geq r \geq 0.79$ for each subscale)(Östberg et al., 1997) and good construct validity as it relate to common stressors and theoretically associated factors as social support and symptoms of postnatal depression (Östberg \& Hagekull, 2000; Östberg et al., 2007; Östberg et al., 1997). In the ABISquestionnaire, SPSQ was used with a 6-point Likert-scale in contrast to the validation by Östberg et al (Östberg et al., 1997) where a 5-point Likert-scales was used.

Parental worries was assessed at four data collections by the question 'Have you worried about anything of the following...' at 2-3 years and 5-6 years follow-ups '... since the child turned one year?', and at 8 and 10-13 years follow-ups '...the last two years?' followed by six to eight items (Likert scales 1-6), each describing a potential age-appropriate risk, see Table 4. A mean value across all items reflecting the level of worries was calculated where a higher value indicates more worries.

Parental dissatisfaction during the child's first year of life was assessed by the same question covering three time-periods: 'How did you get on with being a parent...' (1) '...during the child's first three month?' (2) '...when the child was 3 to 6 month old?' (3) '....when the child was 6 to 12 month old?' answered on 6point Likert-scales from 'very good' to 'very bad'. A weighted mean where 
every month had the same weight reflects the level of dissatisfaction in parenthood during infancy; a higher value indicates more dissatisfaction.

Social support as both the size and the satisfaction of the parent's social support were assessed by a questionnaire derived from Crnic et al. (1983) and previously used in a Swedish form by Östberg and Hagekull (2000). The questionnaire consists of 10 items where the parent first quantifies different parts of his/her social support (ex. 'How many times do you meet your friends/relatives and/or keep in contact via telephone per week?' answered on the categories ' 0 ', ' $1-2$ ', ' $3-4$ ', '5-6', and 'more than 6' scored from 1 to 5), and then estimate how

Table 4. Items in questionnaire about parental worries.

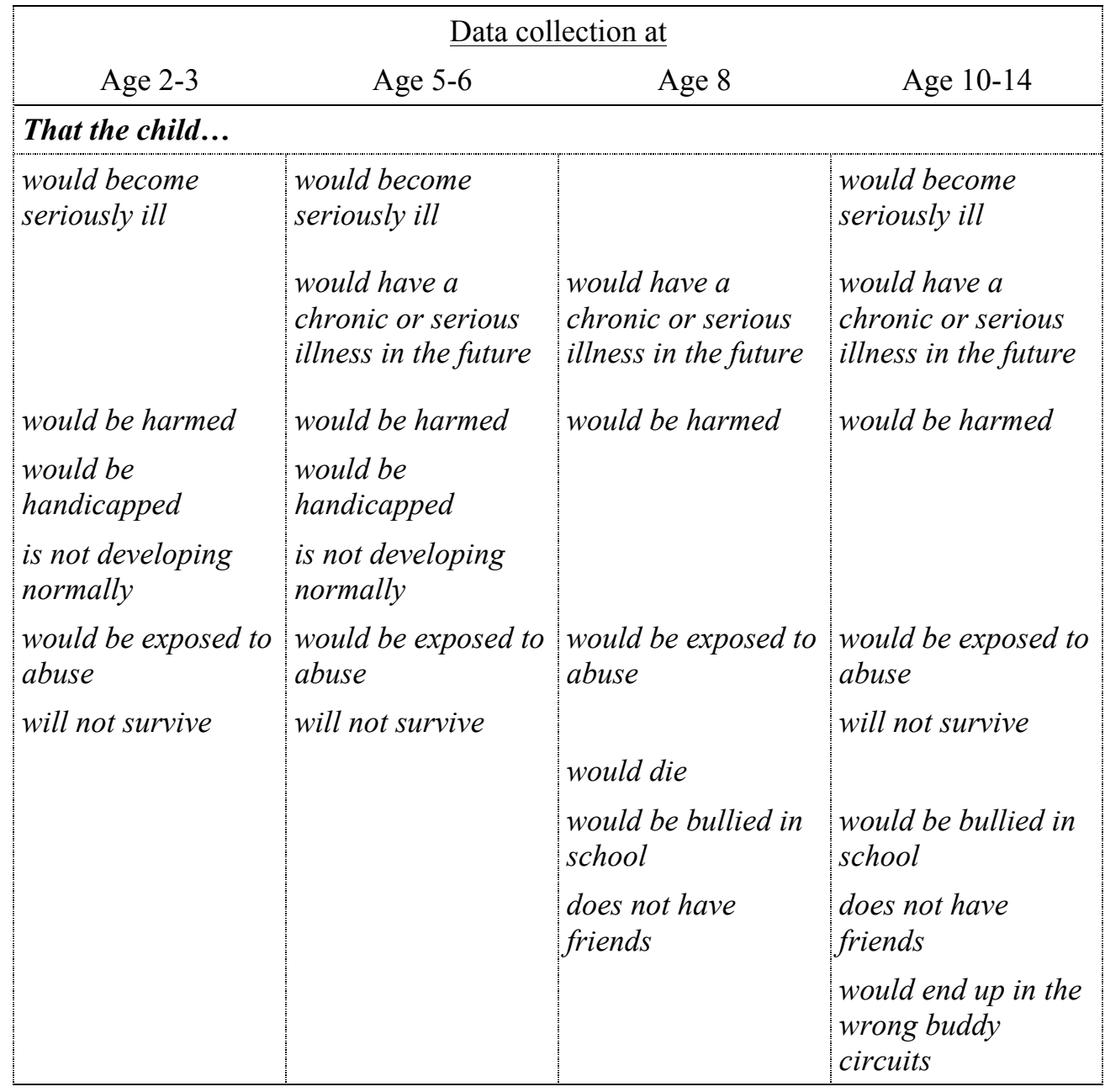


satisfied he/she is with this on a Likert scales from $1=$ 'very satisfied' to $5=$ 'very dissatisfied'. The means were calculated for size as well as satisfaction of social support at each data collection if at least 9 of 10 items were answered.

Adult attachment captures the parent's attachment style to other unspecified adults and was assessed when the child was 2-3 years of age by the 18-item version of the Relationship Scale Questionnaire (RSQ) developed by Griffin and Bartholomew (1994) originally constructed to measure the two dimensions 'model of self' and 'model of other' and four attachment styles. Due to unsatisfied goodness-of-fit-values in other studies (Kurdek, 2002; Roisman et al., 2007) and no previous validation of RSQ in a sample of mothers and fathers to small children, we performed a reconstruction of the dimensionality in Paper 1. The revision resulted in a 14 item questionnaire (SwRSQ-14) with three subscales (Importance of independence, Relationship related anxiety, and Discomfort with closeness) and improved goodness-of-fit values. Hence, the reconstruction was used instead of Griffin and Bartholomew's original construction. Each of the 14 items was answered on Likert scales from 1='not all like me' to 7='very much like me', a mean of each sub-scale was calculated where low value indicates secure attachment.

\subsubsection{The child's temperament and mental health}

The parents' perception of the child's behaviour as fuzzy/difficult in toddlerhood was measured as an indicator of a fuzzy/difficult temperament. It was assessed when the child was at age 2-3 with the Fuzzy-Difficultness subscale ( 7 items) of the Child Characteristics Questionnaire developed to assess the child's difficult temperament, validated and adjusted for 2-year-old children (Lee \& Bates, 1985) and previously used in Sweden by Östberg and Hagekull (2000). Each item was answered on a Likert scale from 1 to 7, a meanvalue was calculated across all items and a higher value indicates a more fuzzy/difficult temperament. 
Table 5. Chronbach's alpha of measurements of psychological stress in the family at each data collection.

\section{Data collection at}

Age 1 Age 2-3 Age 5-6 Age 8 Age 10-14

\section{Psychological stress among parents}

Parenting stress - SPSQ

Complete scale (34 items)

Partial complete scale (23 items)

Incompetence (11 items)

Spouse relationship problems

(5 items)

Role restriction (7 items)

Social isolation (7 items)

Health problems (4 items)

Parental worries (6-8 items)

Parental dissatisfaction (3 items)

Social support

Size (10 items)

Satisfaction (10 items)

Adult attachment - RSQ

Importance of independence (5 items)

Relationship related anxiety (4 items)

Discomfort with closeness (4 items)

The child's temperament and mental health:

Fuzzy/difficult tepmerament (7 items)

Mental health - SDQ-S, Total difficulties score (20 items)

0.75 
Symptoms of mental health problems at age 12-14 years were measured by the Swedish translation (Smedje et al., 1999) of the self-report version of the child's Strengths and Difficulties Questionnaire (SDQ-S; Goodman et al., 1998) as an indicator of psychological stress among the children themselves. The questionnaire consists of 25 items (rated $0=$ "not true', $1=$ 'somewhat true' or $2=$ 'certainly true') across four problem sub-scales (Emotional Symptoms, Peer problems, Hyperactivity-Inattention, and Conduct Problems) and one strength/competence sub-scale (Prosocial behaviour) with 5 items in each subscale. The four problems scales were summed to a total difficulty score (between 0 and 40) where a higher value reflects more symptoms of mental health problems. The self-report version was constructed for children aged 1116 (Goodman, 2001) and Goodman later concluded that SDQ in populationsamples can be used as a dimensional measure of child mental health (Goodman $\&$ Goodman, 2009). The questionnaire has shown good psychometric properties in population samples including children aged 11-13 across Europe (Goodman, 2001; Muris et al., 2004; Rønning et al., 2004; Van Roy et al., 2008) and age 1415 in Sweden (Lundh et al., 2008). Test-retest correlation of the total difficulties score $\mathrm{r}=0.84$ over two weeks among children aged 11-17 in Australia (Mellor, 2004).

\subsubsection{Socio-demographic factors}

Socio-demographic factors were included in the analyses as possible confounding factors for any association between SLEs or stress among parents and T1D or child mental health. The factors were mainly measured in the questionnaire at the child's birth. In Table 6 the variables used in each paper are reported. Here, I only describe the use of parental educational level as an indicator of socioeconomic status, see each paper for a description of the other variables.

The parents educational level were measured at every data collection in ABIS, however, in this thesis only education measured at birth (Papers 2-4) and age 2 (Paper 1) were used. The reason for using the measurement at birth in Papers 3 and 4 that examines periods later in childhood is simply numerical; the data collection at birth have the highest response rate and hence the lowest number of missing values. 


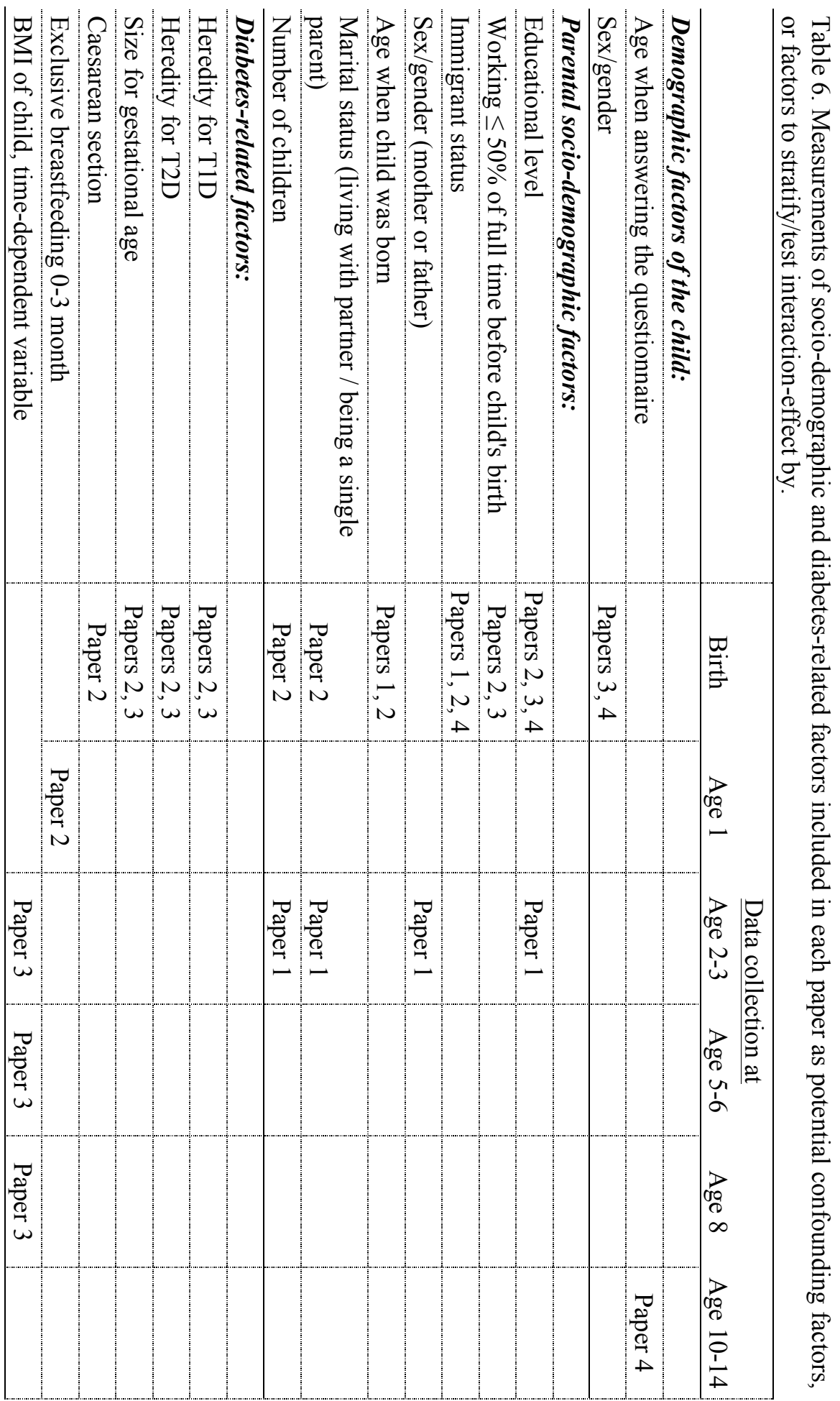


Educational level was at birth assessed by the questions 'What level of education do you have?' and 'What level of education does the child's father have?'. At age 2 'you' were changed to 'mother/you', and 'father' changed to 'father/you' since both could answer the questionnaire. The questions were followed by 6 response options: (1) 9 year compulsory school; (2) secondary school, practical education; (3) secondary school, theoretical education; (4) secondary school (in Swedish folkhögskola); (5) college/university education 13 years; (6) college/university education 3,5 years or more. Because these 6 response options could not be ordered on an ordinal scale, they were recoded to fewer categories in two different ways. In Papers 2 and 3 the mother and the father were jointly coded to all four pairwise combinations of compulsory/secondary school and university education in order to get one variable that describes the socioeconomic position of the child's family. In Paper 1, only educational level of the answering parent was used, and in Paper 4 educational level was only used to adjust for and therefore not jointly coded in order to increase variation. For each parent three groups were made: compulsory school, secondary school, university education in both Papers 1 and 4.

\subsubsection{Diabetes-related factors}

Factors that previously have been discussed as risk factors for T1D and that were measured in the ABIS-questionnaires were included as potential confounding factors for the association between stress and T1D, see Table 6 for the variables and each paper for description.

\subsection{Statistical methods}

\subsubsection{Statistical methods in Papers 1-4}

Several statistical methods have been used across the papers, see each paper for details, with test of significance at $\alpha=0.05$. In general, no adjustments have been made in order to adjust for multiple significance tests, except for some tests in Paper 1. Instead, each result has been judged in relation to its strength and size. Interaction-effects of relevance have been tested in each paper in order to examine if the association under investigation differs between subgroups. Across all studies except Paper 3, participants with missing values on the relevant variables were excluded from the analyses, both due to unit non- 
response (not participating in a data-collection) and item non-response (not answering a specific question). In Paper 3, some missing values on exposure variables were allowed; see details in Paper 3 and discussion regarding imputation below. All statistical analyses in the papers were performed using SPSS/PASW version 18 to 22 .

\subsubsection{Statistical methods in the frame-work}

A few complementary analyses have been performed in the frame-work of the current thesis. All analyses were done in IBM SPSS Statistics, Version 22, release 22.0.0.0.

Bivariate correlation (Pearson) was used to examine associations between measures of stress among parents cross sectional between different measures, and longitudinally within each measurement.

Additional analyses were performed in relation to the results in Paper 4. As in paper 4 was linear regression used with SDQ total scale as outcome.

Population attributable risk (PAR; also called etiological fraction) was used to calculate the proportion of diabetes-cases that hypothetically could be prevented if the exposure were eliminated as a risk-factor, i.e. if the incidence for the total population were reduced to the incidence in the group unexposed. The formula used was

$$
P A R=\frac{P_{\text {exposed }}(H R-1)}{1+P_{\text {exposed }}(H R-1)}
$$

where $P_{\text {exposed }}$ is the proportion in the sample exposed to a SLE, and $H R$ is the estimated Hazard Ratio in Paper 3. This formula has been used in other cohort studies where the follow-up time varies between participants (Benichou, 2001). 


\section{Results}

\subsection{Analyses of non-response}

A dropout analysis was conducted within each paper included in this thesis for the specific study-sample and study-variables. Dropout between data collections associated to socio-demographic factors was analysed in Papers 1, 3, and 4. A lower likelihood for parents to participate was associated with foreign country of birth, lower educational level at child's birth, if the mother had worked $\leq 50 \%$ of full-time before the child's birth, more children, younger age, and single parenthood. The child's sex or year of birth was not found to associate with dropout.

Dropout related to subsequently diagnosis of T1D was analysed in Paper 2 and 3 , where no difference were found in the proportion diagnosed with T1D among those included in the study samples compared to excluded. Dropout related to some possible diabetes-related confounding factors was analysed in Paper 3, no associations to dropout were found for heredity of T1D, heredity of T2D, and size for gestational age.

Dropout related to psychological stress in the family was analysed in Paper 4 (S Table 2 in Paper 4). Less likely to be included in the study-sample were participants that report high levels of parental worries at age 2-3, high on RSQ sub-scale importance with independence at age 2-3, more fuzzy/difficult temperament for their child, experience of at least one SLE for the child at age 8 , and higher on SDQ reported by the child at age 10-14. A SLE for the child reported at age 5 was only slightly above statistical significance. Parenting stress and social support were not found to associate with dropout, nor parental worries at later time-points or experiences of a SLE for the child at age 10-14. 


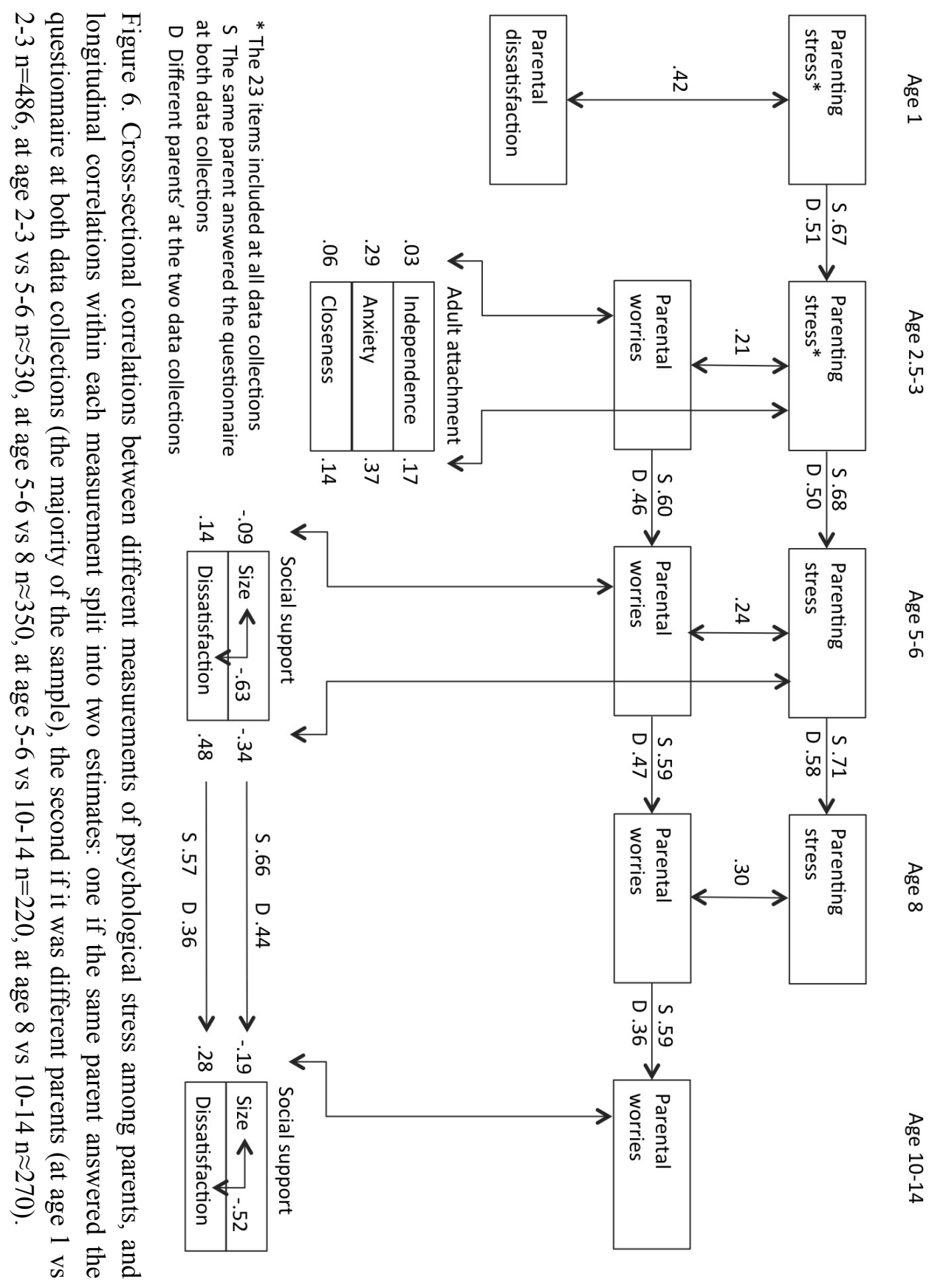




\subsection{Psychological stress in the family}

\subsubsection{Correlations (RQ 1)}

Correlations between measurements of stress among parents are reported in Figure 6. Cross-sectional pairwise correlations (the same person answered) over 0.40 - more then 16\% shared variance - were found between Parenting Stress and two other measurements: parental dissatisfaction, and dissatisfaction with social support. Correlation over time within each measurement were observed as 0.57 or above when the same parent answered at both data collections, and at between 0.36 and 0.58 if answered by different persons.

\subsubsection{Parents' stress and child's mental health (RQ 2)}

In Paper 4, associations between the measurements of psychological stress among the parents during childhood and the child's mental health (assessed with SDQ) in early adolescence were reported. All analyses were adjusted for the socio-demographic factors and child's temperament included in Paper 4. Main effects were found for high parenting stress over time (high 3-4 times vs high 01 time), parental worries over time (high 3-4 times vs high 0-1 time), and dissatisfaction with social support (very satisfied vs both somewhat satisfied and dissatisfied), where higher values were associated with more mental health problems (S Table 3 in Paper 4).

Psychological stress among parents was also tested as moderating factors for the association between exposure of SLEs across childhood and level of SDQ in early adolescence. Moderating effects were found for parenting stress over time (high 3-4 times) and size of social support (small) independent of each other (Table 3 in Paper 4). The main effects of both parenting stress and exposure of SLEs became non-significant when including the interaction-effect in the analysis, (parenting stress high 3-4 times vs $0-1$ time main effect $b=0.12$ $\mathrm{p}=0.816$, interaction with $\mathrm{SLE} b=1.06 \mathrm{p}=0.009$, SLE main $\mathrm{b}=0.271 \mathrm{p}=0.263$ ).

Combining each significant main and interaction effect (interaction of high parenting stress 3-4 times and SLEs; interaction of small social network and SLEs; main effect of high parental worries 3-4 times; main effect of dissatisfied of social support; main effect of somewhat satisfied of social support) and exposure to SLEs across childhood in the same analysis, resulted in a significant 
effect only for the interaction of high parenting stress $(b=1.15, p<0.001)$ when using backward elimination of variables as well as a forward stepwise method. To sum up, child mental health were found associated to parenting stress, parental worries, and the parents social support, however due to the co-variation between measurements only parenting stress in interaction with SLEs were still significant when including all factors in the same model.

\subsection{Stress and the risk of type 1 diabetes}

\subsubsection{Serious life events (RQ 3)}

A SLE experienced any time in childhood (measured by checklist at age 5-6, 8 and 10-14) was associated with an increased risk for manifest T1D up to 13-15 years of age (Table 4 in Paper 3). The results were found after adjusting for possible confounding factors including child's BMI and the parents' educational level. On the contrary, a SLE experienced by the mother during pregnancy or by

Table 7. Absolut risk and Population attributable risk (PAR) in relation to SLE as a risk factor for T1D (Numbers from Table 4 and ESM Table 4 in Paper 3.)

\begin{tabular}{llccccc}
\hline Data collection & Exposure to SLE & $\mathrm{n}$ or $\%$ & $\begin{array}{c}\text { Diabetes } \\
\text { cases }^{\mathrm{a}}\end{array}$ & $\begin{array}{c}\text { Absolute } \\
\text { risk }\end{array}$ & HR $^{\mathrm{b}}$ & PAR \\
\hline Age 5-6 & No & 5079 & 24 & $0.5 \%$ & & \\
& Yes, any kind & 1415 & 13 & $0.9 \%$ & 1.80 & $15 \%$ \\
& Total n & 6494 & 37 & $0.6 \%$ & & \\
Age 8 & & & & & & \\
& No & 2454 & 10 & $0.4 \%$ & & \\
& Yes, any kind & 1031 & 13 & $1.3 \%$ & 2.68 & $33 \%$ \\
& Total n & 3485 & 23 & $0.7 \%$ & & \\
Longitudinally & No & & & & & \\
(time-dependent & Yes, any kind & $30 \%$ & 24 & $1.0 \%$ & 2.84 & $36 \%$ \\
covariate) & Total n & 8214 & 41 & $0.5 \%$ & & \\
\hline
\end{tabular}

${ }^{\mathrm{a}}$ Diagnosed between the data collection and Dec. $31^{\text {st }} 2012$

${ }^{\mathrm{b}}$ Adjusted for heredity for T1D, heredity for type 2 diabetes, size for gestational age, the parents' educational level, and whether the mother worked $\leq 50 \%$ of full time before the child's birth. 
the child during infancy was not found to associate with an increased risk of T1D up to 11-13 years of age (Table 1 in Paper 2). Se each paper for details on analyses.

In the ABIS sample, the cumulative absolute risk for manifest T1D from age 5-6 to $13-15$ years was $1.0 \%$ among children who reported experience of a SLE before diagnosis, and $0.3 \%$ among children who not reported any SLE (Table 7). With $30 \%$ of the ABIS-children exposed to at least one SLE (according to timedependent estimate in Cox-regression in Paper 3) the estimated PAR becomes $36 \%$, which means that statistically $36 \%$ of the diabetes-cases can be attributed to SLE as a risk factor. This number can be compared to for example heredity for T1D, which is often thought of as the most important risk factor for T1D. In ABIS, the estimated HR for 'first degree heredity' (i.e. mother, father, sibling with T1D) was 12.2 , but since only $2.4 \%$ of the children had a first degree relative with T1D, the PAR is only $21 \%$. Concerning 'T1D in the extended family' (grandparents or close relative) $8.1 \%$ was exposed and the estimated HR was 3.3, which gives a PAR of $16 \%$. Added together the total PAR for heredity of T1D in ABIS is $37 \%$.

\subsubsection{Psychological stress among parents (RQ 4)}

None of the variables measuring psychological stress among parents (i.e. parenting stress, parental dissatisfaction, parental worries, and size and dissatisfaction of social support) were found to associate with risk of T1D; neither at age 1 (Table 2 in Paper 2), nor between age 2 and 14 (ESM Table 2 in Paper 3). All variables were treated as linear variables in these analyses. However, different cut-offs have also been tested with similar non-significant results (data not shown).

\subsubsection{Timing of stress (RQ 5)}

Experience of a SLE during pregnancy or infancy (measured by one question each) as well as experienced by the child from birth to age 5-6 years (measured with a checklist) was not found to associate with an increased risk of T1D (Papers 2 and 3). However, there was a tendency for SLEs measured at age 5-6 $(\mathrm{HR}=1.80, \mathrm{p}=0.090$; ESM Table 4 in Paper 3). The experience of a SLE from birth to age 5-6 years (measured in data collection at age 5-6) was also included 
in the model with time-dependent covariates where a significant association to a SLE were found (Table 4 in Paper 3). The experience of at least one SLE between age 6 and 8 years (measured in data collection at age 8) was found to associate with risk of T1D (HR=2.68, $\mathrm{p}=0.020$; ESM Table 4 in Paper 3). Any SLE experienced later in childhood was not examined separately due to small number of diabetes-cases. 


\section{Discussion}

Because valid and reliable measures are necessary to obtain credible results, the first part of the discussion will concern our measurements of psychological stress among the parents, children and families. Thereafter, the discussion concerning childhood stress as a risk factor for T1D will follow. The first aim of this thesis was to evaluate different measurements of psychological stress in the family during childhood, and the conclusions are needed in the discussion on the results regarding the second aim about psychological stress and the risk for T1D.

\subsection{Measurements of stress - reliability and validity}

\subsubsection{Serious life events}

Self-report checklists for stressful life events have been used in half a decade to assess stress (stressors). Despite critique of it's validity, it is still the most common self-report measure of stress (Monroe, 2008). One reason may be because it have been found useful and associate to the HPA-axis as well as mental and somatic health (Cohen et al., 2007; Grant et al., 2004; Turner \& Avison, 2003). Self-report questionnaires are also the only actual option in large-scale studies such as ABIS, in contrast with more time-consuming and detailed interview measures.

\section{Self-report checklists compared to interview measures}

Self-report checklists have mainly been criticized for lack of correspondence with interview measures, and that they do not allow for individual circumstances and differences in responses to events (e.g. response to divorce varies widely). A review by Monroe (2008) report that only between $39 \%$ and $68 \%$ of the life events reported in checklists was valid according to interview criteria. Besides this over-reporting, Duggal et al. (2000) found an underreporting of events occurring prior to depression, where only $32 \%$ of the events were reported in the self-report checklist. Despite the obvious superiority of interviews when assessing detailed information on experiences of life events, self report checklist have been concluded useful and can be recommended when only assessing a summary of overall experiences of life events, without interest in exact timing, 
specific types of events, or individual impact of events (Duggal et al., 2000). Thus, the use of the checklist assessing SLEs across childhood was judged as valid in the main analysis in Papers 3 and 4 regarding 'any kind of SLE' and 'cumulative SLE'. (This topic is also discussed in Paper 3.)

\section{The design of the checklist in ABIS compared to others (face validity)}

The recall-period in the ABIS-checklist varies between 2 to 5 years depending on time of data collection. Of course, the events reported could have been influenced by recall bias, where events could have been forgotten or the timepoint incorrectly remembered. I believe that forgotten events may not have as been emotionally important, thus the underreporting it may cause will probably not have a major impact on the stress-response. Sensitive and undesirable events have also been observed to be underreported previously (Kessler \& Wethington, 1991), in our checklist for example 'conflicts between adults' can be judged as sensitive. Regardless of under- or overestimation, both types of misclassification of an experience of a SLE contribute to an underestimation of the true increase in risk of T1D associated with the experience of a SLE (if a true increase in risk exists). However, this reasoning is only valid as long as the possible bias in the assessment of SLEs not are systematic in relation to diagnosis of T1D, which the prospective design hopefully has protected us from.

The checklist used in ABIS is relatively short and simple measures of life events as stressors compared with other checklist for life events. It consists of 8-14 predefined events for the child, compared to 36 items in Coddington's life event scale for children (Coddington, 1972). Items about violence were not included in contrast to for example Life Incidence of Traumatic Events used in Sweden (Nilsson et al., 2010). We asked if the event had occurred but not how many times, which make it difficult for us to compute valid cumulative measured of number of SLE. Instead, the advantage in the assessments of SLEs in ABIS is the longitudinal design that enables a cumulative measure of SLEs over time (as in Paper 4). This accumulation over time also corresponds well with McEwens concept of allostatic load (McEwen \& Wingfield, 2003).

Each event in the ABIS-checklist was weighted equally, in contrast to Coddington's where every event has a 'life change units' score, or compared to LITE where the participant can rate how much the event upset the child. An equal weight might be a disadvantage because the individual appraisal of the 
event varies greatly. On the other hand, adults may fail to recognize the incidence and magnitude of stress in their children's life.

All events in the checklist do not necessarily need to be negative for the child, especially when the child is small. For example, a death of a relative that the parent was close to but that the child might not have know as well may result in a calmer period with increased physical contact, which can be a positive experience for the child.

\section{Single question concerning SLE (face validity)}

At birth and age 1 a single unspecified question concerning SLEs was included in the questionnaire (i.e. no checklist was used), hence we do not know what kind of life events the parent reported. I suspect a slight underestimation of experiences of a SLE due to the absence of a checklist since only $12 \%$ (1071/8921) reported a SLE at pregnancy or during the child's first year of life (Table 2 in Paper 2) compared to $20-31 \%$ at data collections where a checklist were included (Table 1 in Paper 4). As a measure of an 'objective' stressor, the single question at birth and age 1 lacks validity, however it may still be valid when regarded as a subjective measure of what the parent 'perceive as a serious live event' as the question is worded. Hence, this single question concerning life events correspond more with Lazarus and Folkman's definition of stress as the perception of the event as stressful (Lazarus \& Folkman, 1984).

\section{To summarize/conclude}

Our use of the checklist assessing SLEs across childhood was judged as valid in the main analysis in Papers 3 and 4 regarding 'any kind of SLE' and 'cumulative SLE' even though it may be somewhat under/over-reported. SLEs assessed at birth and 1 year, on the other hand, lacks validity as an 'objective' measure of life events and cannot be compared to the checklist measures, although it still may be valid as a measure of psychological stress. 


\subsubsection{Psychological stress in the family $(R Q 1)$}

How are different dimensions of psychological stress among parents interrelated? Are they all relevant for measuring psychological stress in the family? (Paper 1 and frame-work of the thesis)

\section{Test-retest correlation}

Test-retest correlation reflects both measurement error (i.e. 'instrument reliability') and true variability over time from day-to-day or week-to-week of the phenomenon measured (i.e. intra-individual variation). The stress assessed in ABIS is intend to be chronic psychological stress and I believe it varies over longer time intervals such as month-to-month; it should therefore have high testretest reliability and not vary from day-to-day.

Parenting stress have been examined over 30-days and was found to be stable (Östberg et al., 1997), hence the instrument seems reliable and the phenomenon stable over time which is conformed in the relatively high year-to-year correlations between data collections (Figure 6). SDQ-S total difficulties score as a measure of mental health have been examined over 2 weeks and the testretest was concluded sound among children over 11 years of age (Mellor, 2004). It seems as SDQ-S also is relatively stable over longer time, Goodman reported a correlation of 0.62 over 4-6 month (Goodman, 2001). For parental worries and social support no test-retest correlation has been reported, however, the correlation between data collections (Figure 6) reflects the stability over long time concerning these phenomena. The correlation between data-collections for the same participating parent can also be considered a lower bound of the testretest correlation assuming that the intra-individual variation increases with time.

\section{Internal consistency}

Cronbach's alpha is the most often used psychometric measure of internal consistency, i.e. the degree to which all the items of a scale or instrument measure the same construct or dimension (Cortina, 1993; Cronbach, 1951). However, alpha only measures the degree to which items are inter-related but it does not necessarily tell us anything about uni-dimensionality of the construct or measure (Schmitt, 1996). Instead, the judgement of one underlying construct needs to be made theoretically. Cronbach's alpha is sensitive to the number of items included, where more items give a higher alpha-value. It has been shown 
that even low correlation between items (i.e. $\mathrm{r}=0.30$ ) can result in acceptable alpha (>0.80) if the number of items is many (12 items)(Cortina, 1993). Hence, low alpha can be due to either low number of items or poor correlation between items, as well as high alpha can be due to either many items or high itemcorrelation. What level of alpha that should be regarded as a lower limit for acceptable reliability differs, but cut-offs at 0.70 and 0.75 are usual in research (Streiner et al., 2014). Values higher then 0.90 indicate possible redundancy of items (Streiner et al., 2014).

Measures that were judged as having reliable homogeneity according to Cronbach's alpha in the ABIS-sample were the subscales incompetence, spouse relationship problems, role restriction of SPSQ, parental worries, social support, fuzzy/difficult temperament of the child. Although alpha for the SPSQ-subscale spouse relationship problems at some data collections were somewhat low, I consider it good given the few items included. Alpha for the SPSQ-subscales social isolation and health problems were observed low. Parental dissatisfaction consists of the same question covering different time-periods so high internal consistency is not necessarily desirable because the level of dissatisfaction may change over time. Cronbach's alpha is also not the best suitable measure of reliability for SDQ-S, since the items only have three response options and therefore cannot be considered as a continues scale.

Our revised version of RSQ with 3 sub-scales was in Paper 1 judged as having acceptable reliability with Cronbach's alpha $>0.65$ for both mothers and fathers, which can be criticized because higher cut-offs often are used. However, one should keep in mind that the subscales only have 4-5 items each and therefore the alpha may be somewhat low indicating larger amount of random error in the total scale due to few items, but not necessarily low item-to-item correlation. The intraclass correlation (ICC) for a single measure (reliability index of a single item; i.e. if the sub-scale hypothetically should be measured by only one of the items included) in the RSQ sub-scales was $0.32,0.36$, and 0.33 , compared with 0.19 for SPSQ complete scale (34 items), 0.40 for spouse relationship problems ( 5 items), or 0.58 for worries (6 items) at the same data collection. Given the somewhat low Cronbach's alpha due to the combination of low interitem correlation and few items, I conclude that the scale has slightly low reliability. However, associations were found between SPSQ subscale social isolation and relationship related anxiety and discomfort with closeness (Paper 
1) despite the large proportion of random error, indicating that these subscales still are useful.

\section{Associations between dimensions of stress among parents (construct validity)}

Parenting stress, parental worries, adult attachment, and size of social support clearly measure different domains of psychological stress in the family since only weak correlations $(<0.4)$ was found in the ABIS-sample. The domain of parenting stress however, seems to overlap somewhat with both parental dissatisfaction and dissatisfaction with social support. The correlation with parental dissatisfaction is expected, since SPSQ includes one specific question concerning satisfaction in the role as a parent.

Satisfaction with social support on the other hand, is not conceptually the same thing as parenting stress. Instead, social support can be beneficial to metal health and the buffering hypothesis suggests that social support has a buffering role where adequate support protects against negative consequences of stress (Cohen $\&$ Wills, 1985). It has also been hypothesized that social support has a direct (main) effect on the level of stress, where a positive effect exists regardless of the individuals' levels of stress (Cohen \& Wills, 1985). That association has been confirmed in Sweden by Östberg where a main effect on parenting stress was found for size of social support (Östberg \& Hagekull, 2000). In the current study, both size and satisfaction associate to parenting stress, as expected. Size and satisfaction with social support are also highly correlated as expected, however, it seems to be the perception of adequate support, not the actual size of the support that protects most from feelings of stress connected to parenthood. The covariations between measurements became apparent in the analyses in Paper 4, where each of parenting stress, size and satisfaction with social support were found as moderating factors for the association between SLEs and child mental health, but satisfaction with social support became redundant when including all three moderating factors in the same model. The result in Paper 4 suggests that parenting stress and size of social support are two distinct phenomenons.

In Paper 1, the revision of RSQ was concluded successful with dimensions that fit to the theory of adult attachment. The revised version of RSQ was used in analyses in Paper 4, and in contrast to our expectations no associations were found to child mental health. As concluded earlier in this thesis, RSQ has 
somewhat low reliability, which seems reasonable in the light of this nonfinding, as I still theoretically believe that the parent's adult attachment can be important for the child's coping with stressful experiences. Attachment-related avoidance has for example been associated to less sensitive and supportive parenting (Jones et al., 2015). According to the theory of adult attachment, different attachment styles are associated with different strategies for emotional regulation and support seeking as well as the possibility to benefit from social support (Collins \& Feeney, 2000; Mikulincer et al., 2003). Results also suggests that secure mothers cope better with pregnancy and transition to parenthood then insecure mothers (Jones et al., 2015), which corresponds to our results where anxious parents report higher levels of parenting stress (Paper 1 and Figure 5). Based on theory and previous findings, I argue that adult attachment rather should be understood as a factor contributing to stressful experiences (e.g. as a moderating factor) than a stressor in it self for the parents.

To estimate stress in the family by one parent

To estimate psychological stress in the family by only asking one familymember is an obvious limitation. However, this limitation may not be as important as one might think. The correlation in ABIS of parenting stress, worries and social support over time when different parents have answered the questionnaires was observed to be high in order to be an inter-individual correlation. This correlation can be understood as stability within the family (at family-level) and cannot be used as a measure of interpersonal reliability because the level of stress in the family may vary over time. However, as in the case of test-retest correlation, I argue it can be seen as a lower limit of the interpersonal correlation.

\section{To summarize/conclude}

The measurements of parenting stress, parental worries, social support, and child mental health (SDQ-S) were judge as having adequate reliability in the ABISsample as far as they could be examined. Only RSQ were judged to have somewhat low reliability with a large amount of random error. The combination of parenting stress, parental worries and size of social support assesses different aspects of psychological stress in the family, although social support can also be understood as a buffering factor. 


\subsubsection{Proxies for psychological stress of the child (RQ2)}

Does psychological stress among the parents associate to the child's mental health in early adolescence? Can it be used as a proxy for the level of psychological stress of the child? (Paper 4)

\section{The parents' psychological stress and the child's mental health}

Several dimensions of psychological stress among the parents during childhood were in Paper 4 separately found to associate to child mental health in early adolescence both as main effects, and moderating the effects of SLEs. High parenting stress across childhood was only associated in combination with experiences of SLEs, i.e. parenting stress was only found negative for the child's mental health if it persisted through childhood and if the child had experienced at least one SLE in childhood. Also a small social network for the parent was found to be negative only in combination with experiences of at least one SLE in childhood. These results suggest that an absence of high parenting stress, and adequate parental social support may have buffering effects on child mental health during stressful experiences. Parental worries and satisfaction with social support, on the other hand, were found to associate to child mental health regardless if the child had experienced a SLE or not. However, only chronically high parenting stress in combination with the experience of a SLE was associated with mental health when combining all dimensions in the same model, indicating covariation between dimensions of psychological stress among parents and the child's experiences of SLEs across childhood. These results suggest that of the dimensions examined, the combination of high parenting stress across childhood and experiences of SLEs have greatest importance for childrens mental health. However, the results should be interpreted carefully as both parenting stress and child mental health above all are stable over time, as well as the associations are suggested to be reciprocal (Mackler et al., 2015). Hence, I cannot comment on the causality, despite the prospective study design. See discussion in Paper 4 for more details.

\section{Stress and mental health}

Mental ill-health is usually seen as one (out of several) consequences of stress. Both stressors, such as stressful life events or adverse socioeconomic conditions (Grant et al., 2004), perceived stress (Bovier et al., 2004), and stress hormones (Gustafsson et al., 2006; Michels et al., 2012) have all been associated to various mental health problems in childhood and early adulthood. However, mental ill- 
health may also sensitize the person for continued stressful experiences and increase the risk for experiencing new negative life events, as suggested by the stress sensitization hypothesis (McLaughlin et al., 2010).

\section{Proxies for psychological stress of the child}

Regarding parenting stress and social support, our results suggest they both have impact on the child's level of psychological stress because the association to child mental health was only found in combination with experiences of SLEs. Regardless if our results indicate a buffering effect or are a finding due to cumulative stress, both mechanisms links to the child's experiences of stressful events or to support with coping (see discussion in Paper 4). Hence, I suggest they both can be used as proxies for psychological stress of the child.

The influence of parental worries on child mental health may be through insecure parent-child attachment and overprotecting/overinvolved parenting. Anxiety among parents have been found to associate to anxiety in children (Kovacs \& Devlin, 1998), and to internalizing problems in children both directly and mediated by overprotecting and overinvolved parenting (Bayer et al., 2006). Excessive worries among parents may be a behaviour derived from an insecure parent-child attachment pattern that in turn affects the child's emotional regulation and coping strategies (Bowlby, 1969). Our measure of attachmentrelated anxiety was however only weakly correlated to parental worries, probably due to low reliability.

The explanation behind the association between the psychological stress among parents and children's mental health do not necessarily need to be solely child stress. Other factors such as individual factors of the child (e.g. temperament) or neuropsychiatric diagnosis (e.g. ADHD) may also influence both the parents' stress and the child's mental health. In the analyses, it was possible to adjust for fuzzy/difficult temperament as a confounding factor, however other possible confounding factors may still partly explain the associations found.

\section{Other factors related to the child's experiences of stress}

Stress in the family as the parents' psychological stress is one out of several factors that influences the child's experiences of stress. Individual factors of the child such as cognition and intellectual competence as well as coping style have been found to protect from negative mental health outcomes despite experiences 
of adverse life (Flouri et al., 2010; Grant et al., 2006; Seiffge-Krenke, 2000). Although individual factors are desirable to measure, they are difficult to measure among small children: It is very difficult, if not impossible, to ask the child.

Besides the family, other microsystems surrounding the child may be of importance such as school or leisure activities where both perceived stress and relations to peers, teachers and other adults may be relevant (Deater-Deckard et al., 1998; Grant et al., 2006). Factors related to the parent-child relation may also be of importance for the children's mental health such as parenting behaviour and the parents' emotional support (Deater-Deckard et al., 1998; Låftman \& Östberg, 2006; Mackler et al., 2015). Also other parts of the exosystem besides the parents' social network may indirectly influence the child, for example the parents' work-related stress and the climate at school. The chronosystem may as well influence the child's perceptions of stress, for example the family history of relationships, history of violence, and history of mental ill-health.

\section{To summarize/conclude}

The parents' psychological stress across childhood associate to children's mental health in early adolescence, especially chronically high parenting stress in combination with experiences of SLEs. Our measurements of psychological stress among parents (parenting stress, social support, parental worries) may be used as proxies for psychological stress of the child, with the knowledge that both individual factors and other systems besides the family also may affect the child's level of stress.

\subsection{Stress and the risk of type 1 diabetes}

\subsubsection{Serious life events (RQ 3)}

Are the child's experiences of serious life events in childhood associated with higher risk of manifest type 1 diabetes? (Papers 2 and 3)

Our study is the first prospective study that can confirm an associations between an experiences of a serious life event in childhood and an increase in risk of $\mathrm{T} 1 \mathrm{D}$, as previously found in several retrospective case-control (Karavanaki et 
al., 2008; Leaverton et al., 1980; Siemiatycki et al., 1989; Sipetić et al., 2007; Stein \& Charles, 1971; Thernlund et al., 1995; Vialettes et al., 1989; Vlajinac et al., 2006).

\section{Independent of child's BMI}

The increase in risk found was independent of the child's BMI across childhood, as in line with a previous finding (Karavanaki et al., 2008). However, to us this finding was a bit surprising, since overweight is one factor that may cause insulin resistance and therefore is a possible risk factor for T1D according to the beta-cell stress hypothesis and according to empirical findings (Cardwell et al., 2010; Kibirige et al., 2003). Obesity has also been suggested to be closely related with psychological stress, mediated through changes in food intake and exercise level as well as metabolic changes due to increased cortisol levels (Gundersen et al., 2011). These associations have been confirmed in ABIS; both between psychological stress and obesity (Koch et al., 2008), and between psychological stress and cortisol (Koch et al., 2010). Nevertheless, our results indicate that stress can be regarded a risk-factor for T1D independently of BMI of the child, as well as next to BMI as one other possible other risk-factor (although BMI was not found to associate with risk of T1D in our study, see Paper 3).

\section{Independent of the parents' educational level}

The parents' educational level was in our study associated with diabetes risk, where the combination of a lowly educated mother and a highly educated father increased the risk of T1D (Papers 2 and 3), which is partly in line with previous findings linking low maternal education to diabetes risk (Blom et al., 1989; Du Prel et al., 2007; Soltész et al., 1994). Low educational level is often regarded a stressor and an indicator of adverse living conditions and low social status (see introduction). On the other side, educational level influences the living patterns associated with health, such as food habits (i.e. De Irala-Estevez et al., 2000). Despite the possible confounding role of educational level, our results regarding SLEs were found after adjusting for the parents' educational level, hence our results suggest that the SLE-related stress that increases the risk for T1D is not caused by the parents' educational level.

\section{To summarize/conclude}

Our study is the first prospective study that can confirm associations between 
serious life events and increased risk of T1D. Our results were independent of the child's BMI and the parents' educational level.

\subsubsection{Psychological stress among parents (RQ 4)}

Is psychological stress among the parents associated with higher risk of manifest type 1 diabetes for their children? (Papers 2 and 3)

Psychological stress among the parents was investigated in the ABIS-study as a possible risk factor for T1D since the parents are important for the child's perception of stress, as discussed above. However, our results could not confirm any general association between the parents' perception of stress and risk of T1D for their child. As far as I know, only one prior retrospective study has examined some dimension of stress in the family, where chaotic family life was associated with risk of T1D, but the parents' social support was not as is in line with our results (Thernlund et al., 1995).

Earlier in the current thesis, I concluded that our measurements of psychological stress among parents (parenting stress, lack of social support, and parental worries) could be used as proxies for psychological stress of the child. So the question is: Why do we find associations with T1D for experience of a SLE but not for stress among the parents if they both can be regarded as sources of stress for the child? One explanation might be the different nature of the phenomena, where SLEs usually are sudden events in time in contrast to the parental stress that is quite stable and slowly changing over time (Mackler et al., 2015; Rantanen et al., 2015; Östberg et al., 2007). The associations with cortisol and with immunological markers previously found in ABIS concerned a composite measure of stress including both the experience of a SLE, high parenting stress, high level of worries, and dissatisfaction of social support (Carlsson et al., 2014; Koch et al., 2008). So unfortunately, I cannot make any conclusion based on those earlier findings.

In Paper 4 were experiences of SLEs in childhood associated to poorer child mental health (emotional and behavioural problems) only if the parents reported chronically high levels of parenting stress, or small social network. Earlier, Thernlund et al. (Thernlund et al., 1995) found associations with T1D for negative life events experienced any time during the entire childhood only if the 
child had difficulties with adjustment. Maybe a mechanism linking the parents' stress to T1D is via adjustment to stressors, rather then the straight/direct association tested in the current study? I.e. an experience of a SLE may be a stronger risk factor for T1D in the subgroup of families where the parents have chronically high levels of psychological stress. Different life events affect children differently (se discussion above), and the family climate is one influencing factor. Future studies, maybe within ABIS, can investigate this possible moderating effect further.

\section{To summarize/conclude}

Our results could not confirm any general association between psychological stress among parents and the risk of T1D among their children. Future studies can examine if psychological stress among parents may function as a moderating factor for the increase in risk due to the experience of a serious life event.

\subsubsection{Timing of stress (RQ 5)}

Is the timing of stress relevant for the risk of type 1 diabetes? Is stress more important during infancy, toddler/preschool age, or early school age? (Papers 2 and 3)

SLEs during pregnancy and the first year of life was measured with one unspecified question each and is not comparable to SLEs assessed by checklists at age 5-6 and 8, hence no conclusions will be made by comparing these results. Although, both measurements of SLEs point in the same direction: that SLEs (both unspecified events perceived as stressful, and specified events in a checklist) experienced early in life not seems to increase the risk for T1D on their own (Papers 2 and 3), but in addition with events experienced later in childhood the risk was increased (Paper 3). The results also suggest that events experienced between ages 6-8 years do increase the risk of T1D on their own (Paper 3).

Our findings are somewhat in line with prior retrospective studies, where associations with diagnosis were found for specific types of events experienced during the entire childhood (Karavanaki et al., 2008; Thernlund et al., 1995) or between age 5-9 (Hägglöf et al., 1991). However, our study is the first study to 
my knowledge suggesting that any kind of serious life event experienced at any time in childhood may increase the risk for T1D, in contrast to prior studies who failed to find such evidence (Karavanaki et al., 2008; Thernlund et al., 1995; Vialettes et al., 1989). One possible explanation to why the prior studies have failed to find associations for any kind of life events experienced sometime during the entire childhood may be differences in study-design that causes bias in measurement of events experienced more then one year prior to diagnosis. While we measure SLEs longitudinally across childhood with recall-periods between 2 and 5 years, the prior studies are all retrospective with a recall-period as long as the child's entire life. Hence, it is likely to believe that events that the child perceived as very stressful (Thernlund et al., 1995), or events of parental dispute or divorce (Karavanaki et al., 2008) are easier to remember over the years for the parent then other kinds of events not perceived as very stressful for the parent (e.g. new adult or child in the family).

In our study, the year previous diagnosis was not examined because of measurement-reasons; i.e. the time between event and diagnosis could not be accurately assessed because we don't know the exact time of exposure only a time-interval.

\section{To summarize/conclude}

The experience of a SLE any time during the entire childhood seems to be of importance; however, a event experienced between ages 6-8 do solely increases the risk of T1D, but any event experienced earlier in life did not. The result indicates that the experience of a SLE does not function as a trigger starting the immunological process, but may instead function as a modifying factor possibly influencing the on-going beta-cell destruction leading to manifest diabetes. Unfortunately, we did not have the data needed to investigate whether psychological stress can be a factor that punches the autoimmune process over the tipping point to manifest T1D.

\subsubsection{Stress in relation to genetic risk of T1D}

The ABIS-sample is a population-based sample of children born in a specific region without any other selection criteria in contrast to other cohort studies examining risk of T1D that select participants based on genetic markers associated with risk. Between 15-25\% of the children has in Sweden been 
observed to have HLA-DQ genotype associated with increased risk of T1D, however also children with low- risk genotypes may occasionally develop T1D (Carlsson et al., 2012). The inclusion of children regardless of genetic risk as a strength of the ABIS-sample. Unfortunately, we had no possibility to stratify for genetic risk, hence future studies are needed to examine if the increase in risk for T1D associated with a SLE only exists in a subgroup of children with specific genetics, e.g. high or low-risk genes. However, the current study could conclude that heredity for T1D (parents, siblings or grandparents with T1D) does not seem to affect the association found between SLEs and T1D.

\subsubsection{The significance of SLEs and possible prevention}

Heredity is on an individual level a stronger risk factor for the development of T1D than SLEs, although most children who develop T1D don't have a close family member with T1D. On a population-level, SLEs may be even more important then heredity (T1D among parents or siblings) according to the size of PAR, i.e. the proportion of diabetes cases that hypothetically can be prevented if the risk factor were eliminated as a risk factor. The importance of SLEs on the population-level is primarily due to the large proportion exposed to at least one SLE - a proportion that likely is underestimated in study 3 .

Divorce, that a grandparent dies, or other life events happens to most children, and it is not desirable to avoid major life events because stressful experiences are a part of life. Instead, prevention may be possible by reducing the child's perception of stress that follows the experience of a life event. Paper 4 suggests that adequate social support and low levels of stress among parents reduces the negative effect of stressful life events on mental health. Maybe supportive prevention directed towards families has a positive effect on the risk for diabetes as well? Nevertheless, it is important to remember that even though an increase in risk was found, the absolute risk to develop T1D is still relatively small; in our study one percent of the population who reported the experience of at least one SLE were subsequently diagnosed.

\subsubsection{Possible sources of bias}

Can the exposure to SLEs be biased systematically in relation to diagnosis of T1D despite the prospective design? Yes, it is possible that SLEs reported such 
as death/illness in the family are related to T1D in the family or other diseases related to risk of T1D. The association between SLEs and T1D were also analysed without death/illness in the family as events, and the association was still significant (Paper 3). This finding strengthens the trueness of our results regardless if reports of deaths/illnesses are related to T1D.

On the other hand is the estimation of exposure to a SLE most likely an underestimation in Paper 3 (se paragraph 4.3.3), probably equally distributed across diabetes cases and non-diabetes cases. The natural consequence of this bias - given that the experience of a SLE truly increases the risk of T1D - is an overestimation of risk in the unexposed-group (because some of them truly are exposed), which results in an underestimation of the 'true' increase in risk due to any experience of a SLE.

We know there was a bias in identification of children with diagnosis. A control of the ABIS-children towards prescription of insulin in the drug prescription register (Läkemedelsregistret) revealed a few new diabetes-cases not registered in Swediabkids. This control was unfortunately done after the analysis in Paper 3. However, because the group of children without diabetes in ABIS is very large, the possible few unidentified cases do not contribute to any significant dilution effect. The main consequence is rather that the statistical analyses have less power then if all cases had been identified.

The opposite, that cases without diabetes are identified as cases, is most unlikely. However, there is a very small possibility that children with MODY have been diagnosed as type 1 .

\section{To summarize/conclude}

Our results were most likely not biased by events of death/illness possible related to T1D. Bias in estimation of SLEs probably underestimates any 'true' association. Some diabetes cases were not identified through Swediabkids, resulting in less power then best possible. 


\subsection{Methodological issues}

\subsubsection{The prospective design}

The greatest strength of the current study is the prospective design. Although the design entails drawbacks such as large dropout and in our case a homogenous sample (discussed below), the prospective design is the best possible studydesign for the research question 'does exposure to stress increases the risk of T1D?'. Our prospective study-design results in measurement data of exposure that is unbiased in relation to the outcome, in contrast to case-control studies where the participants' status on the outcome may influence their recall of the exposure as observed for psychological stress as an exposure (Metcalfe et al., 2008). In all studies, except Paper 1, data from more than one data collection are used; hence we take advantage of the prospective design in Papers 2-4.

\subsubsection{Sample and generalizability}

All families with at least one child born in during two years in southeast Sweden were asked to participate in the study. Hence, the ABIS-sample is a total-sample of a cohort in a specific region, although with a significant proportion of nonresponse. Therefore the ABIS-sample is homogenous in terms of the geographical and political environment as well as the experiences/exposures is linked to a specific generation. Hence, generalizations of our results to other kinds of populations should be made with some caution. If an association between serious life events and risk of diabetes exists in other populations outside Scandinavia, in countries with less economic wealth and equality, and children born during other periods in time - should preferably be examined in studies with samples from those populations.

The major strength with the ABIS-sample is that is the inclusion of all children regardless of genetic risk of T1D, hence our results can be generalized to all children within similar populations.

The parents' or the mother's experiences of stress?

Throughout the thesis I use the wording 'the parents' psychological stress. However, the great majority (85-97\%) of the participating parents at each data collection between 1 and 14 years of age are mothers. Hence, our results regarding the parents' psychological stress may actually mostly reflect the 
mother's psychological stress. On the other hand (as discussed earlier in 4.1.2), the correlation over time was high between parents for our measures of psychological stress, indicating that both parents often experience approximately similar level of stress. Furthermore, I believe that the parent who answered the questionnaire is active in their parenting and involved in the child's life, although I cannot verify that assumption. Hence, the results are limited to a selfselected half of all parents of the ABIS-children, but probably reflect much of the family level of stress.

\subsubsection{Non-response}

The major drawback in longitudinal studies is a large amount of dropout over time. In ABIS, the initial response rate was $75 \%$, which is good for a comprehensive questionnaire survey. However, data collections have in ABIS been conducted at six time-points, resulting in dropout at each data collection. When data from several data-collections are analyzed simultaneously, the proportion of participants with missing data cumulates and becomes large; only $8 \%$ of the ABIS-sample participates in all data collections. Below, I will discuss to what extent non-response should be regarded a problem, and how missing data are handled in the statistical analyses.

\section{Missing data}

The problem with dropout is not the missing cases in themselves but instead non-response bias, i.e. bias due to systematic dropout. With systematic dropout, the sample is not random; hence one of the basic assumptions for accurate statistical inference are not fulfilled. Attrition between data-collections in our sample was not at random in relation to socioeconomic and demographic factors as expected, although all groups were still represented in the sample. Regarding the main exposure, various assessments of stress, I expected that non-stressed parents are more likely to participate. Such was the case for five of the 20 measurements tested in Paper 4, where dropout seems to be somewhat systematic in relation to parental worries, adult attachment, the child's temperament, the child's experiences of a SLE, and the child's mental health at age 12-14. Dropout seems to be at random in relation to parenting stress and social support, and because the sample is large it is very likely that dropout truly is completely at random. 
Regarding our main outcome, diagnosis of T1D, the dropout between data collections seems to be somewhat at random although due to the relative small sample size ( $n=58$ with T1D) a completely randomness of the dropout cannot be concluded. When investigating associations, as in this study, systematic dropout may bias the result if it is related to the association under investigation. I believe that it is very unlikely that the association found between experience of a SLE and diagnosis of T1D is a result of systematic dropout. To be a result of dropout, the dropout should be more common among diabetes-cases without any previous experiences of any SLE, and non-cases with previous experiences of SLEs, which is most unlikely thanks to the prospective design.

\section{To impute or not impute?}

In Papers 1, 2 and 4, no imputation techniques were used; hence participants with missing values were excluded from the analyses. The reason was simply that the number of participants was sufficient for the analyses. In Paper 2, the power in the analyses was increased by extending the group of cases (with high risk children) instead of imputing missing values. To only include participants with complete data, and not allowing for missing observations, may create bias if missing are not at random. However, as discussed above and concluded in each paper, the results found are not likely due to patterns in missing data.

In Paper 3, the use of time-dependent variables, where a value was updated across time only if a new valid value was present, becomes a kind of imputation technique in practice. In the analyses of psychological stress among parents, a missing value was imputed with the value from the closest previous data collection where a valid value existed. In the analyses regarding SLEs, the timedependent variable indicates an experience of a SLE sometime earlier in childhood, but the use of a time-dependent variable also had the consequence that the proportion of children exposed to SLEs became underestimated. What happened was that a 'no' was updated to a 'yes' when a valid value existed, but where the value was missing (e.g. due to non-response in that data collection) it continued to be 'no', even though the child may well have experienced a SLE during the period of missing observations.

\subsubsection{Type 1 error - result by chance}

Very few of the analyses made were adjusted for multiple statistical testing, i.e. 
the probability for the statistical test to show false significance (type 1 error) was $5 \%$ in each single test. Performing many tests gives that 1 of 20 tests at alpha 0.05 becomes significant by chance, given that the sample and dropout are random. However, the main results discussed in each paper all have $p<0.01$ as well as they are judged by their effect-size and robustness (i.e. if the result remains when operationalizing or testing the association in different ways). Hence, the probability of wrong conclusions based on random results still exists, although the likelihood is small.

\subsubsection{Type 2 error - power to falsify}

In Papers 2 and 3, one limitation was the small number of diabetes cases ( $n=42$ and 41 in the analyses regarding the main results) as a result of the large dropout over time. Despite limited power a clear association was found between SLEs during childhood and risk of T1D. But the range of the confidence intervals estimated for all stress-variables was large; therefore it is not possible to reject the possibility for either the parents' stress or SLEs experienced early in life to contribute moderately to the development of T1D. Thus, further studies with higher power need to be conducted. 


\subsection{Summary and conclusions}

\subsubsection{Summary}

The checklist of SLEs was found to be valid in the main analysis regarding any kind of SLE and cumulative SLEs even though it might be somewhat under/over-reported. SLEs assessed at birth and 1 year, on the other hand, lacks validity as an 'objective' measure of life events and cannot be compared to the checklist measures, however it may still have validity as a measure of events perceived as stressful.

The measurement of parenting stress, parental worries and size of social support were judged as reliable measures assessing different aspects of psychological stress in the family, although social support can also be understood as a buffering factor. These measurements were all associated to children's mental health in early adolescence, especially chronically high parenting stress in combination with experiences of SLEs. Hence, these measurements (parenting stress, parental worries and the parents' social support) may be used as proxies for psychological stress of the child, with the knowledge that both individual factors of the children and other systems besides the family may also affect children's level of stress. Only the measure of adult attachment (RSQ) was judged to have somewhat low reliability with a large amount of random error, however it was associated, as expected, with parenting stress and may still be useful although it did not associate with children's mental health.

The current study is the first unbiased prospective study that can confirm an association between the experience of a serious life event and an increase in risk of T1D. The result was independent of the child's BMI and the parents' educational level. Experiences of a SLE any time during childhood (up to age 14 years) seems to be of important; however, a SLE experienced in early school age (ages 6-8 years) also solely increases the risk of T1D, but SLEs experienced earlier in childhood did not. Our result was most likely not biased by events of death/illness possible related to T1D, however, possible biases in estimation of SLEs probably underestimates any 'true' association.

Our results could not confirm any association between psychological stress among parents (i.e. parenting stress, parental dissatisfaction, parental worries, and the parents' social support) and the risk of T1D among their children. 


\subsubsection{Conclusions}

The self-assessment measurements of parenting stress (subscales incompetence, spouse relationship problems, and role restriction), parental worries, and social support in combination with a checklist for stressful life events experienced by the child is useful in large-scale studies as proxies for psychological stress of the child.

Experiences of serious life events in childhood are one environmental factor that seems to be involved in the development of type 1 diabetes. Therefore we suggestes that psychological stress, especially stressful life events, should be included in future studies examining the development of type 1 diabetes.

Psychological stress among parents does not seem to be a major risk factor for T1D in their children. However, the parents' stress and social support seems to be of importance for child's mental health after experiences of stressful life events.

\subsubsection{More general conclusions}

Despite the limitations with self-assessment measurements of psychological stress are self-report questionnaires essential in large-scale epidemiological studies.

Although ABIS is a large prospective study, the power is still low in sub-group analyses and analyses regarding rare exposures. I conclude that the ABIS-study needs more then 13-15 years of follow-up time in order to deeply investigate stress as a risk factor. Hence, I recommend future prospective studies to work hard to increase the participation rate over time.

It is important for the health care system to support parents' and their children in order to prevent negative consequences of experiences of stressful life events; e.g. by clinicians working with children in connection with health care contacts due to traumatic life events, or supportive initiatives that aims to reduce the parents level of stress in parenthood and strengthen their social network. 


\subsubsection{Suggestions for future research}

I recommend future large-scale studies that investigate stress in children to use both a checklist for stressful life events and questionnaires to assess stress among parents as proxies for psychological stress among children. However, future studies should possibly broaden the perspective and also include measurements of stress within other microsystems such as school and leisure activities, as well as relations to parents, peers and other adults, beside stress among parents.

Future research examining factors contributing to the development of T1D should include stress as a possible risk factor, especially experiences of serious life events preferably using checklists and trying to assess the individual impact of the event on the child. However, more research needs to be done regarding stress and development of T1D, and our results need to be confirmed in prospective studies with higher power. I suggest future studies should investigate:

- Does stress interact with genetic risk?

- Where in the autoimmune process is stress a risk factor?

- Are there critical or sensitive periods during children's physical development when stress is particularly harmful?

- Are the results valid in other populations; in other geographic areas and among children born during other time-periods?

- Does psychological stress among parents function as a moderating factor for the increase in risk due to serious life events?

- Does stress experienced by the child within school, in relation to peers, or in other contexts outside the family increase the risk of T1D? 


\section{Epilogue to worried parents}

So should you worry for diabetes now if you have gone through a divorce or know that your child has been exposed to other stressful life events? My answer is simply No! Stressful life events are a part of life and children need to experience changing events in order to learn how to manage these events in a functional way later in their adult life. The most important you can do as a parent is to be responsive and supportive to your child.

Regarding the risk of type 1 diabetes it should be remembered that it still is a quite rare disease; in our sample only 5 in each 1000 children have the diagnose at age 14 . Hence, the absolute majority of the children in our sample experience life events without the consequence of a diabetes diagnosis. At last, it needs to be pointed out that all the results in this thesis only can be interpreted on a structural level and they can never be applied on individual children. 


\section{References}

Abidin, R. R. (1990) Parenting Stress Index (PSI) Manual. Odessa, FL, USA:Psychological Assessment Resources, Inc.

Atkinson, M. A., Eisenbarth, G. S., \& Michels, A. W. (2014) Type 1 diabetes. The Lancet, 383(9911), 69-82.

Bayer, J. K., Sanson, A. V., \& Hemphill, S. A. (2006) Parent influences on early childhood internalizing difficulties. Journal of Applied Developmental Psychology, 27(6), 542-559.

Benichou, J. (2001) A review of adjusted estimators of attributable risk. Statistical methods in medical research, 10(3), 195-216.

Blom, L., Dahlquist, G., Nyström, L., Sandström, A., \& Wall, S. (1989) The Swedish childhood diabetes study - social and perinatal determinants for diabetes in childhood. Diabetologia, 32(1), 7-13.

Bovier, P. A., Chamot, E., \& Perneger, T. V. (2004) Perceived stress, internal resources, and social support as determinants of mental health among young adults. Quality of Life Research, 13(1), 161-170.

Bowlby, J. (1969) Attachment and loss. Vol. 1. Attachment. London:Hogarth.

Bradley, R. H. \& Corwyn, R. F. (2002) Socioeconomic status and child development. Annual review of psychology, 53(1), 371-399.

Bronfenbrenner, U. (1979) The ecology of human development: experiments by nature and design. :Harvard University Press (E-Book 1996).

Brown, G. W. \& Harris, T. O. (1978) Social origins of depression: A study of psychiatric disorder in women. London:Tavistock Publications.

Cardwell, C., Stene, L., Joner, G., Davis, E., Cinek, O., Rosenbauer, J., ... Patterson, C. (2010) Birthweight and the risk of childhood-onset type 1 diabetes: a meta-analysis of observational studies using individual patient data. Diabetologia, 53(4), 641-651. 
Carlsson, A., Kockum, I., Lindblad, B., Engleson, L., Nilsson, A., Forsander, G., ... Lernmark, Å. (2012) Low risk HLA-DQ and increased body mass index in newly diagnosed type 1 diabetes children in the Better Diabetes Diagnosis study in Sweden. International journal of obesity, 36(5), 718-724.

Carlsson, E., Frostell, A., Ludvigsson, J., \& Faresjö, M. (2014) Psychological Stress in Children May Alter the Immune Response. The Journal of Immunology, 192(5), 2071-2081.

Coddington, R. D. (1972) The significance of life events as etiologic factors in the diseases of children. II. A study of a normal population.. J Psychosom Res, 16(3), 205-213.

Cohen, S., Janicki-Deverts, D., \& Miller, G. E. (2007) Psychological stress and disease. Jama, 298(14), 1685-1687.

Cohen, S., Kamarck, T., \& Mermelstein, R. (1983) A global measure of perceived stress. Journal of health and social behavior, 24(4), 385-396.

Cohen, S., Kessler, R. C., \& Gordon, L. U. (1995) Measuring Stress: A Guide for Health and Social Scientists. New York:Oxford University Press.

Cohen, S. \& Wills, T. A. (1985) Stress, social support, and the buffering hypothesis.. Psychological bulletin, 98(2), 310.

Collins, N. L. \& Feeney, B. C. (2000) A safe haven: An attachment theory perspective on support seeking and caregiving in intimate relationships. Journal of Personality and Social Psychology, 78(6), 1053-1073.

Cortina, J. M. (1993) What is coefficient alpha? An examination of theory and applications.. Journal of applied psychology, 78(1), 98.

Crnic, K. A., Greenberg, M. T., Ragozin, A. S., Robinson, N. M., \& Basham, R. B. (1983) Effects of stress and social support on mothers and premature and full-term infants. Child development, 54(1), 209-217.

Cronbach, L. J. (1951) Coefficient alpha and the internal structure of tests. Psychometrika, 16(3), 297-334.

Dalgard, O. S., Dowrick, C., Lehtinen, V., Vazquez-Barquero, J. L., Casey, P., Wilkinson, G., ...The ODIN Group. (2006) Negative life events, social support and gender difference in depression. Social psychiatry and psychiatric epidemiology, 41(6), 444-451. 
Danese, A. \& McEwen, B. S. (2012) Adverse childhood experiences, allostasis, allostatic load, and age-related disease. Physiology \& Behavior, 106(1), 29-39.

De Irala-Estevez, J., Groth, M., Johansson, L., Oltersdorf, U., Prattala, R., \& Martínez-González, M. A. (2000) A systematic review of socio-economic differences in food habits in Europe: consumption of fruit and vegetables. European journal of clinical nutrition, 54(9), 706-714.

Deater-Deckard, K., Dodge, K. A., Bates, J. E., \& Pettit, G. S. (1998) Multiple risk factors in the development of externalizing behavior problems: Group and individual differences. Development and psychopathology, 10(03), 469-493.

Dhabhar, F. S. (2009) Enhancing versus suppressive effects of stress on immune function: implications for immunoprotection and immunopathology. Neuroimmunomodulation, 16(5), 300-317.

Dhabhar, F. S. (2008) Enhancing versus suppressive effects of stress on immune function: implications for immunoprotection versus immunopathology. Allergy, Asthma and Clinical Immunology, 4(1), 2.

Dowd, J. B., Simanek, A. M., \& Aiello, A. E. (2009) Socio-economic status, cortisol and allostatic load: a review of the literature. International journal of epidemiology, 38(5), 1297.

Du Prel, J.-B., Icks, A., Grabert, M., Holl, R. W., Giani, G., \& Rosenbauer, J. (2007) Socioeconomic conditions and type 1 diabetes in childhood in North Rhine-Westphalia, Germany. Diabetologia, 50(4), 720-728.

Dube, S. R., Fairweather, D., Pearson, W. S., Felitti, V. J., Anda, R. F., \& Croft, J. B. (2009) Cumulative childhood stress and autoimmune diseases in adults. Psychosomatic medicine, 71(2), 243.

Duggal, S., Malkoff-Schwartz, S., Birmaher, B., Anderson, B. P., Matty, M. K., Houck, P. R., ... Frank, E. (2000) Assessment of life stress in adolescents: Selfreport versus interview methods. Journal of the American Academy of Child \& Adolescent Psychiatry, 39(4), 445-452.

Essex, M. J., Klein, M. H., Cho, E., \& Kalin, N. H. (2002) Maternal stress beginning in infancy may sensitize children to later stress exposure: Effects on cortisol and behavior. Biological Psychiatry, 52(8), 776-784. 
Evans, G. W. \& Kim, P. (2007) Childhood poverty and health cumulative risk exposure and stress dysregulation. Psychological Science, 18(11), 953-957.

Flouri, E., Tzavidis, N., \& Kallis, C. (2010) Adverse life events, area socioeconomic disadvantage, and psychopathology and resilience in young children: the importance of risk factors' accumulation and protective factors' specificity. European child \& adolescent psychiatry, 19(6), 535-546.

Goodman, A. \& Goodman, R. (2009) Strengths and difficulties questionnaire as a dimensional measure of child mental health. Journal of the American Academy of Child \& Adolescent Psychiatry, 48(4), 400-403.

Goodman, R. (2001) Psychometric properties of the strengths and difficulties questionnaire. Journal of the American Academy of Child \& Adolescent Psychiatry, 40(11), 1337-1345.

Goodman, R., Meltzer, H., \& Bailey, V. (1998) The Strengths and Difficulties Questionnaire: a pilot study on the validity of the self-report version. European child \& adolescent psychiatry, 7(3), 125-130.

Grant, K. E., Compas, B. E., Stuhlmacher, A. F., Thurm, A. E., McMahon, S. D., \& Halpert, J. A. (2003) Stressors and child and adolescent psychopathology: moving from markers to mechanisms of risk.. Psychological bulletin, 129(3), 447.

Grant, K. E., Compas, B. E., Thurm, A. E., McMahon, S. D., \& Gipson, P. Y. (2004) Stressors and child and adolescent psychopathology: Measurement issues and prospective effects. Journal of Clinical Child and Adolescent Psychology, $33(2), 412-425$.

Grant, K. E., Compas, B. E., Thurm, A. E., McMahon, S. D., Gipson, P. Y., Campbell, A. J., ... Westerholm, R. I. (2006) Stressors and child and adolescent psychopathology: Evidence of moderating and mediating effects. Clinical psychology review, 26(3), 257-283.

Griffin, D. W. \& Bartholomew, K. (1994) \{The metaphysics of measurement: The case of adult attachment. $\}$. Advances in Personal Relationships, 5(), 17-52.

Gröschl, M., Rauh, M., \& Dörr, H.-G. (2003) Circadian rhythm of salivary cortisol, 17alpha-hydroxyprogesterone, and progesterone in healthy children. Clinical Chemistry, 49(10), 1688-1691. 
Gundersen, C., Mahatmya, D., Garasky, S., \& Lohman, B. (2011) Linking psychosocial stressors and childhood obesity. Obesity Reviews, 12(5), e54-e63.

Gustafsson, P. E., Gustafsson, P. A., \& Nelson, N. (2006) Cortisol levels and psychosocial factors in preadolescent children. Stress Health, 22(1), 3-9.

Gustafsson, P. E., Janlert, U., Theorell, T., \& Hammarström, A. (2010) Lifecourse socioeconomic trajectories and diurnal cortisol regulation in adulthood. Psychoneuroendocrinology, 35(4), 613-623.

Harjutsalo, V., Sjöberg, L., \& Tuomilehto, J. (2008) Time trends in the incidence of type 1 diabetes in Finnish children: a cohort study. The Lancet, 371(9626), 1777-1782.

Hinkle Jr, L. E., Evans, F. M., \& Wolf, S. (1951) Studies in Diabetes Mellitus: III: Life History of Three Persons with Labile Diabetes, and Relation of Significant Experiences in Their Lives to the Onset and Course of the Disease. Psychosomatic medicine, 13(3), 160-183.

Holmes, T. H. \& Rahe, R. H. (1967) The Social Readjustment Rating Scale. Journal of psychosomatic research, 11(2), 213-218.

Hägglöf, B., Blom, L., Dahlquist, G., Lönnberg, G., \& Sahlin, B. (1991) The Swedish childhood diabetes study: indications of severe psychological stress as a risk factor for type 1 (insulin-dependent) diabetes mellitus in childhood. Diabetologia, 34(8), 579-583.

Johnson, S. B. (1980) Psychosocial factors in juvenile diabetes: A review. Journal of Behavioral Medicine, 3(1), 95-116.

Jones, J. D., Cassidy, J., \& Shaver, P. R. (2015) Parents' Self-Reported Attachment Styles A Review of Links with Parenting Behaviors, Emotions, and Cognitions. Personality and Social Psychology Review, 19(1), 44-76.

Karavanaki, K., Tsoka, E., Liacopoulou, M., Karayianni, C., Petrou, V., Pippidou, E., ... Dacou-Voutetakis, C. (2008) Psychological stress as a factor potentially contributing to the pathogenesis of type 1 diabetes mellitus. Journal of endocrinological investigation, 31(5), 406-415.

Karlén, J., Ludvigsson, J., Hedmark, M., Faresjö, Å., Theodorsson, E., \& Faresjö, T. (2015) Early Psychosocial Exposures, Hair Cortisol Levels, and Disease Risk. Pediatrics, (), doi: 10.1542/peds.2014-2561. 
Kendler, K. S., Thornton, L. M., \& Prescott, C. A. (2001) Gender differences in the rates of exposure to stressful life events and sensitivity to their depressogenic effects. American Journal of Psychiatry, 158(4), 587-593.

Kessler, R. C. (1979) Stress, social status, and psychological distress. Journal of Health and Social behavior, 20(3), 259-272.

Kessler, R. C., McGonagle, K. A., Swartz, M., Blazer, D. G., \& Nelson, C. B. (1993) Sex and depression in the National Comorbidity Survey I: Lifetime prevalence, chronicity and recurrence. Journal of affective disorders, 29(2), 8596.

Kessler, R. C., McLaughlin, K. A., Green, J. G., Gruber, M. J., Sampson, N. A., Zaslavsky, A. M., ... Williams D. R. (2010) Childhood adversities and adult psychopathology in the WHO World Mental Health Surveys. The British Journal of Psychiatry, 197(5), 378-385.

Kessler, R. C. \& Wethington, E. (1991) The reliability of life event reports in a community survey. Psychological Medicine, 21(03), 723-738.

Kibirige, M., Metcalf, B., Renuka, R., \& Wilkin, T. (2003) Testing the Accelerator Hypothesis The relationship between body mass and age at diagnosis of type 1 diabetes. Diabetes Care, 26(10), 2865-2870.

Knip, M. (2012) Descriptive epidemiology of type 1 diabetes - is it still in?. Diabetologia, 55(5), 1227-1230.

Knip, M., Veijola, R., Virtanen, S. M., Hyöty, H., Vaarala, O., \& Åkerblom, H. K. (2005) Environmental triggers and determinants of type 1 diabetes. Diabetes, 54(suppl 2), S125-S136.

Knip, M., Virtanen, S. M., \& Åkerblom, H. K. (2010) Infant feeding and the risk of type 1 diabetes. The American journal of clinical nutrition, 91(5), 1506S$1513 \mathrm{~S}$.

Koch, F. S. (2009) Stress and obesity in childhood. (Doctoral dissertation) Faculty of Health Sciences, Linköping University (Linköping University Medical Dissertation No. 1100)

Koch, F. S., Ludvigsson, J., \& Sepa, A. (2010) Parents' psychological stress over time may affect children's cortisol at age 8. J Pediatr Psychol, 35(9), 950-959. 
Koch, F. S., Sepa, A., \& Ludvigsson, J. (2008) Psychological stress and obesity. The Journal of pediatrics, 153(6), 839-844.

Kovacs, M. \& Devlin, B. (1998) Internalizing disorders in childhood. Journal of Child Psychology and Psychiatry, 39(1), 47-63.

Kurdek, L. A. (2002) On being insecure about the assessment of attachment styles. Journal of Social and Personal Relationships, 19(6), 811-834.

Lazarus, R. S. \& Folkman, S. (1984) Stress, Appraisal, and Cooping. New York:Springer Publishing Company.

Leaverton, D. R., White, C. A., McCormick, C. R., Smith, P., \& Sheikholislam, B. (1980) Parental loss antecedent to childhood diabetes mellitus. Journal of the American Academy of Child Psychiatry, 19(4), 678-689.

Lee, C. L. \& Bates, J. E. (1985) Mother-child interaction at age two years and perceived difficult temperament. Child development, 56(5), 1314-1325.

Littorin, B., Sundkvist, G., Nyström, L., Carlson, A., Landin-Olsson, M., Östman, J., ...Wibell L. (2001) Family characteristics and life events before the onset of autoimmune type 1 diabetes in young adults: a nationwide study. Diabetes Care, 24(6), 1033-1037.

Ludvigsson, J. (2006) Why diabetes incidence increases - a unifying theory. Annals of the New York Academy of Sciences, 1079(1), 374-382.

Ludvigsson, J., Ludvigsson, M., \& Sepa, A. (2001) Screening for prediabetes in the general child population: maternal attitude to participation. Pediatric diabetes, 2(4), 170-174.

Lundh, L.-G., Wångby-Lundh, M., \& Bjärehed, J. (2008) Self-reported emotional and behavioral problems in swedish 14 to 15 -year-old adolescents: A study with the self-report version of the strengths and difficulties questionnaire. Scandinavian journal of psychology, 49(6), 523-532.

Låftman, S. B. \& Östberg, V. (2006) The pros and cons of social relations: An analysis of adolescents' health complaints. Social science \& medicine, 63(3), 611-623.

Mackler, J. S., Kelleher, R. T., Shanahan, L., Calkins, S. D., Keane, S. P., \& O'Brien, M. (2015) Parenting Stress, Parental Reactions, and Externalizing Behavior From Ages 4 to 10. Journal of Marriage and Family, 77(2), 388-406. 
McEwen, B. S. \& Wingfield, J. C. (2003) The concept of allostasis in biology and biomedicine. Hormones and Behaviour, 43(1), 2-15.

McEwen, B. S. \& Wingfield, J. C. (2010) What's in a name? Integrating homeostasis, allostasis and stress. Hormones and Behaviour, 57(2), 105-11.

McLaughlin, K. A., Conron, K. J., Koenen, K. C., \& Gilman, S. E. (2010) Childhood adversity, adult stressful life events, and risk of past-year psychiatric disorder: a test of the stress sensitization hypothesis in a population-based sample of adults. Psychological medicine, 40(10), 1647-1658.

Mellor, D. (2004) Furthering the use of the strengths and difficulties questionnaire: reliability with younger child respondents. Psychological assessment, 16(4), 396.

Metcalfe, C., Macleod, J., Smith, G. D., \& Hart, C. L. (2008) The scope for biased recall of risk-factor exposure in case-control studies: evidence from a cohort study of Scottish men. Scandinavian journal of public health, 36(4), 442445 .

Michels, N., Sioen, I., Huybrechts, I., Bammann, K., Vanaelst, B., De Vriendt, T., ... De Henauw, S. (2012) Negative life events, emotions and psychological difficulties as determinants of salivary cortisol in Belgian primary school children. Psychoneuroendocrinology, 37(9), 1506-1515.

Mikulincer, M., Shaver, P. R., \& Pereg, D. (2003) Attachment theory and affect regulation: The dynamics, development, and cognitive consequences of attachment-related strategies. Motivation and emotion, 27(2), 77-102.

Monroe, S. M. (2008) Modern approaches to conceptualizing and measuring human life stress. Annual Review of Clinical Psychology, 4(), 33-52.

Muris, P., Meesters, C., Eijkelenboom, A., \& Vincken, M. (2004) The selfreport version of the Strengths and Difficulties Questionnaire: Its psychometric properties in 8-to 13-year-old non-clinical children. British Journal of Clinical Psychology, 43(4), 437-448.

Nilsson, D., Gustafsson, P. E., \& Svedin, C. G. (2010) Self-reported potentially traumatic life events and symptoms of post-traumatic stress and dissociation. Nordic Journal of Psychiatry, 64(1), 19-26. 
Nolen-Hoeksema, S. (2012) Emotion regulation and psychopathology: The role of gender. Annual Review of Clinical Psychology, 8(), 161-187.

Nolen-Hoeksema, S. (1987) Sex differences in unipolar depression: evidence and theory. Psychological Bulletin, 101(2), 259.

Patterson, C., Guariguata, L., Dahlquist, G., Soltész, G., Ogle, G., \& Silink, M. (2014) Diabetes in the young - a global view and worldwide estimates of numbers of children with type 1 diabetes. Diabetes Research and Clinical Practice, 103(2), 161-175.

Rantanen, J., Tillemann, K., Metsäpelto, R.-L., Kokko, K., \& Pulkkinen, L. (2015) Longitudinal study on reciprocity between personality traits and parenting stress. International Journal of Behavioral Development, 39(1), 6576.

Rawshani, A., Landin-Olsson, M., Svensson, A.-M., Nyström, L., Arnqvist, H. J., Bolinder, J., \& Gudbjörnsdottir, S. (2014) The incidence of diabetes among 0-34 year olds in Sweden: new data and better methods. Diabetologia, 57(7), 17.

Roisman, G. I., Holland, A., Fortuna, K., Fraley, R. C., Clausell, E., \& Clarke, A. (2007) The Adult Attachment Interview and Self-Reports of Attachment Style: An empirical rapprochement. Journal of Personality and Social Psychology, 92(4), 678-697.

Rosa, E. M. \& Tudge, J. (2013) Urie Bronfenbrenner's theory of human development: its evolution from ecology to bioecology. Journal of Family Theory \& Review, 5(4), 243-258.

Rønning, J. A., Handegaard, B. H., Sourander, A., \& Mørch, W.-T. (2004) The Strengths and Difficulties Self-Report Questionnaire as a screening instrument in Norwegian community samples. European Child \& Adolescent Psychiatry, 13(2), 73-82.

Schmitt, N. (1996) Uses and abuses of coefficient alpha. Psychological assessment, 8(4), 350-353.

Segerstrom, S. C. \& Miller, G. E. (2004) Psychological stress and the human immune system: a meta-analytic study of 30 years of inquiry. Psychological bulletin, 130(4), 601-630. 
Seiffge-Krenke, I. (2000) Causal links between stressful events, coping style, and adolescent symptomatology. Journal of adolescence, 23(6), 675-691.

Selye, H. (1956) The stress of life. New York, NY, US:McGraw-Hill.

Sepa, A. (2004) The Stress Hypothesis. (Doctoral dissertation) Faculty of Health Sciences, Linköping University (Linköping University Medical Dissertations No. 838)

Sepa, A., Frodi, A., \& Ludvigsson, J. (2005) Mothers' experiences of serious life events increase the risk of diabetes-related autoimmunity in their children. Diabetes Care, 28(10), 2394-2399.

Sepa, A., Frodi, A., \& Ludvigsson, J. (2004) Psychosocial correlates of parenting stress, lack of support and lack of confidence/security. Scandinavian Journal of Psychology, 45(2), 169-179.

Siemiatycki, J., Colle, E., Campbell, S., Dewar, R. A., \& Belmonte, M. M. (1989) Case-control study of IDDM. Diabetes Care, 12(3), 209-216.

Sipetić, S., Vlajinac, H., Marinkovi, J., Kocev, N., Milan, B., Ratkov, I., \& Sajic, S. (2007) Stressful life events and psychological dysfunctions before the onset of type 1 diabetes mellitus. Journal of Pediatric Endocrinololgy \& Metabolism, 20(4), 527-534.

Smedje, H., Broman, J.-E., Hetta, J., \& Von Knorring, A.-L. (1999) Psychometric properties of a Swedish version of the 'Strengths and Difficulties Questionnaire'. European Child \& Adolescent Psychiatry, 8(2), 63-70.

Soltész, G., Jeges, S., \& Dahlquist, G. (1994) Non-genetic risk determinants for type 1 (insulin-dependent) diabetes mellitus in childhood. Acta Paediatrica, 83(7), 730-735.

Springer, K. W., Mager Stellman, J., \& Jordan-Young, R. M. (2012) Beyond a catalogue of differences: a theoretical frame and good practice guidelines for researching sex/gender in human health. Social science \& medicine, 74(11), 1817-1824.

Stein, S. P. \& Charles, E. (1971) Emotional factors in juvenile diabetes mellitus: a study of early life experience of adolescent diabetics. American Journal of Psychiatry, 128(6), 700-704. 
Streiner, D. L., Norman, G. R., \& Cairney, J. (2014) Health measurement scales: a practical guide to their development and use, 5th Ed.. Oxford, UK:Oxford University Press.

Swick, K. J. \& Williams, R. D. (2006) An analysis of Bronfenbrenner's bioecological perspective for early childhood educators: Implications for working with families experiencing stress. Early Childhood Education Journal, 33(5), 371-378.

Tauriainen, S., Oikarinen, S., Oikarinen, M., \& Hyöty, H. (2011) Enteroviruses in the pathogenesis of type 1 diabetes. Seminars in Immunopathology, 33(1), 4555.

Taylor, S. E., Lerner, J. S., Sage, R. M., Lehman, B. J., \& Seeman, T. E. (2004) Early environment, emotions, responses to stress, and health. Journal of personality, 72(6), 1365-1394.

Thernlund, G. M., Dahlquist, G., Hansson, K., Ivarsson, S. A., Ludvigsson, J., Sjöblad, S., \& Hägglöf, B. (1995) Psychological stress and the onset of IDDM in children. Diabetes Care, 18(10), 1323-1329.

Tiet, Q. Q., Bird, H. R., Davies, M., Hoven, C., Cohen, P., Jensen, P. S., \& Goodman, S. (1998) Adverse life events and resilience. Journal of the American Academy of Child \& Adolescent Psychiatry, 37(11), 1191-1200.

Turner, R. J. \& Avison, W. R. (2003) Status variations in stress exposure: Implications for the interpretation of research on race, socioeconomic status, and gender. Journal of Health and Social Behavior, 44(4), 488-505.

Turner-Cobb, J. M. (2005) Psychological and stress hormone correlates in early life: a key to HPA-axis dysregulation and normalisation. Stress, 8(1), 47-57.

Van Roy, B., Veenstra, M., \& Clench-Aas, J. (2008) Construct validity of the five-factor Strengths and Difficulties Questionnaire (SDQ) in pre-, early, and late adolescence. Journal of Child Psychology and Psychiatry, 49(12), 13041312 .

Vanaelst, B., De Vriendt, T., Ahrens, W., Bammann, K., Hadjigeorgiou, C., Konstabel, K., ... De Henauw, S. (2012) Prevalence of psychosomatic and emotional symptoms in European school-aged children and its relationship with childhood adversities: results from the IDEFICS study. European child \& adolescent psychiatry, 21(5), 253-265. 
Vanaelst, B., Huybrechts, I., Bammann, K., Michels, N., Vriendt, T., Vyncke, K., ... De Henauw, S. (2012) Intercorrelations between serum, salivary, and hair cortisol and child-reported estimates of stress in elementary school girls. Psychophysiology, 49(8), 1072-1081.

Vialettes, B., Ozanon, J., Kaplansky, S., Farnarier, C., Sauvaget, E., LassmannVague, V., ... Vague, P. (1989) Stress antecedents and immune status in recently diagnosed type 1 (insulindependent) diabetes mellitus. Diabete \& Metabolisme, 15(1), 45-50.

Vlajinac, H., Sipetić, S., Marinković, J., Bjekić, M., Kocev, N., \& Sajić, S. (2006) The Belgrade childhood diabetes study - comparison of children with type 1 diabetes with their siblings. Paediatric and Perinatal Epidemiology, 20(3), 238-243.

Williams, G. \& Pickup, J. C. (2004) Handbook of diabetes. :Wiley-Blackwell.

Zung, A., Blumenfeld, O., Shehadeh, N., Dally Gottfried, O., Tenenbaum Rakover, Y., ... The Israel IDDM Registry Study Group (2012) Increase in the incidence of type 1 diabetes in Israeli children following the Second Lebanon War. Pediatric Diabetes, 13(4), 326-333.

Östberg, M. \& Hagekull, B. (2000) A structural modeling approach to the understanding of parenting stress. Journal of Clinical Child Psychology, 29(4), 615-625.

Östberg, M., Hagekull, B., \& Hagelin, E. (2007) Stability and Prediction of Parenting Stress. Infant and Child Development, 16(2), 207-223.

Östberg, M., Hagekull, B., \& Wettergren, S. (1997) A measure of parental stress in mothers with small children: dimensionality, stability and validity. Scandinavian Journal of Psychology, 38(3), 199-208. 


\section{Acknowledgments (Tack)}

Allra först ett stort tack till alla barn och föräldrar som deltagit i ABIS genom att svara på långa och många frågeformulär och lämna prover. Tack också till Rita och Ann-Marie för det ovärderliga arbetet med ABIS datainsamlingar, och alla ni som tidigare varit inblandade $\mathrm{i}$ att samla in den otroligt häftiga och fantasieggande kohortdata som finns!

Sen vill jag tacka mina handledare såklart! Anneli för att jag fått fråga dig om allt och alltid fått genomtänkta svar tillbaka. För det nära samarbetet i början som varit en superbra grund att stå på. För din respekt till mina tankar och tro på min förmåga. John för inte minst allt trevligt småprat, men också små men betydelsefulla funderingar. Johnny för din långa erfarenhet av diabetesforskning och för att ABIS finns. Felix för härliga diskussioner och kloka funderingar och idéer, både som en doktorandkollega och sedan handledare.

Alla doktorand-vänner under åren ska också ha ett stort tack för det utbyte av doktoranderfarenheter som gett perspektiv och stöttat. Tack Ester, Sven, Felix igen, Jelmer, Johanna, Ida, Anna, Joel m.fl.

Tack till kollegorna i korridoren i Linköping för fika och vardagsprat, blandat med seminarier och presentationer. Framförallt Humlan och alla på genus och medicin som hållit mitt genustänkande levande. Tack också till mina nya kollegor i Umeå på Allmänmedicin, och speciellt till Klara som fixade in mig där! Men också Evelina, Per och ni andra som jag redan nämnt och er som jag inte nämnt. Ert stöd och er pepp har givit kraft såhär i sluttampen på arbetet.

Att vara doktorand och skriva en avhandling är något som påverkar hela livet, så därför vill jag också tacka familj och vänner. Först och främst vill jag tacka min mamma och pappa som gett mig kreativiteten och nyfikenheten som varit en förutsättning för mitt arbete med avhandlingen. Tack också till mina syskon för att ni finns och gör mig glad!

Därefter vill jag tacka mina barn, som bara genom sin tillblivelse gett mig insikter om den föräldrastress och det sociala stöd som jag innan bara abstrakt 
försökt att förstå. De har också tagit mig tillbaka till nuet vid stunder då arbete allt för mycket snurrat runt $\mathrm{i}$ huvudet och de har påmint mig om att livet är så mycket mer än bara arbete. De har påmint mig om att arbetet inte behöver bli perfekt, bara gott nog, eftersom det finns två små liv som också behöver min tid!

Tack Niklas. Du har varit en otrolig klippa under den sista tiden med avhandlingsarbetet. Tack också för alla roliga ovetenskapliga diskussioner vi haft i köket kring vetenskapen, psykologin och dess brister. De har utvecklat mitt tänkande!

Tack också till alla jag levt nära under åren som doktorand för att ni stått ut med en stressad, något glömsk doktorand med lite för mycket arbetsmoral för sitt eget bästa. Tack för att ni hittat på roliga saker med mig! Tack Sven, Jonas, kolletiv-kamraterna på Nygatan i Linköping, på Manhattan, och i Blåvitt kollektiv i Umeå. 


\section{Appendix - SLE questionnaires in Swedish}

\section{SLE experienced by the child measured in data collection...}

at age 1

44 Har barmet varie med orm magon

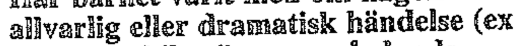

गö

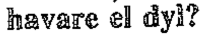

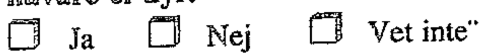

Om ja, vad/vilka

ift toxt

at age 5-6

108. Har Barnet utsatts för något som Du uppfattar som en svår livshändelse sen det föddes?

$\square \mathrm{Ja} \square \mathrm{Nej}$

Om Ja, vad?

a Anhörig som dött

b Föräldrar som skilt sig ....................................

C Ny vuxen i familjen

$d$ Nytt/nya bam i familjen (nytt biologiskt

syskon räknas ej)

e Många konflikter mellan vuxna i hemmet ....

$f$ Kontakt med stödfamilj

9 Stödåtgärder frăn sociala myndigheter

(socialbidrag räknas ej)

h Fosterhemsplacerad

Annat, vad?

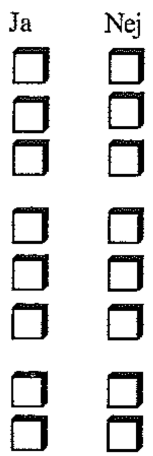

txt 


\section{at age 8}

\section{Har barnet varit med om någon svår livshändelse senaste 2 åren? \\ $\square$ Ja $\square$ Nej}

Om Ja, kryssa för ett eller flera alternativ nedan och försök uppskatta hur stressande händelsen/rna varit för barnet.

Hur stressande har händelsen varit för barnet?

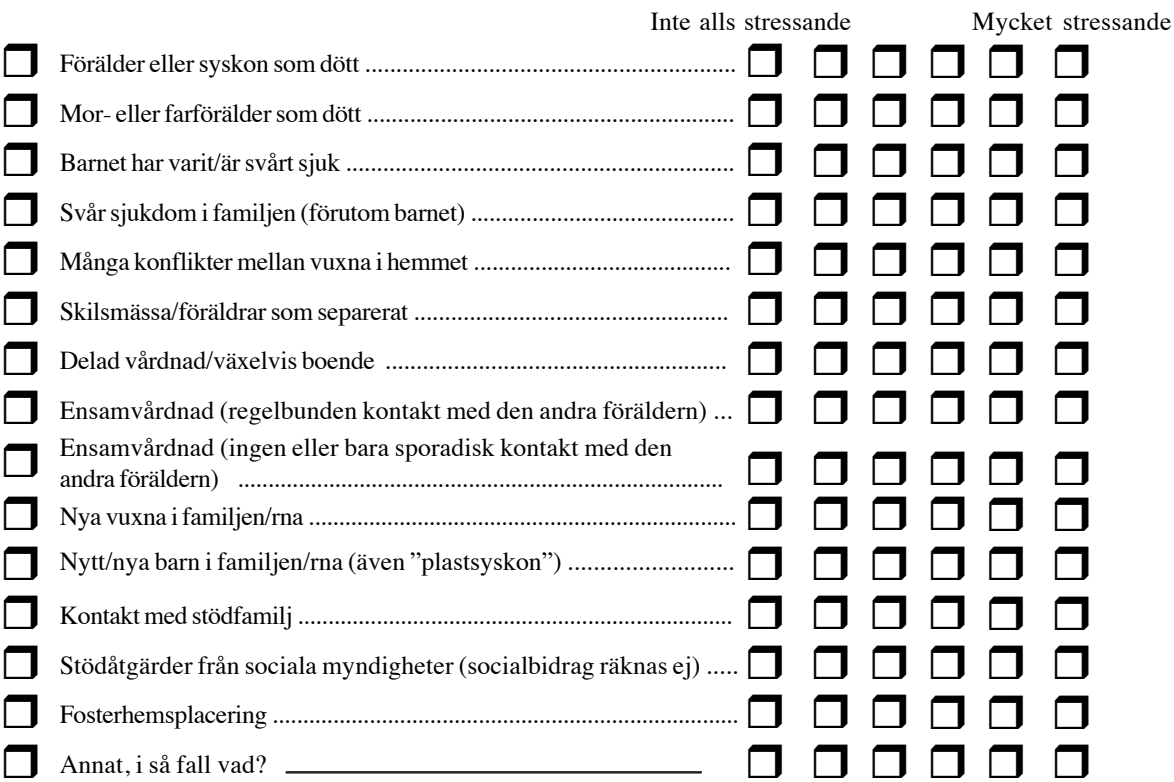




\section{at age $10-14$}

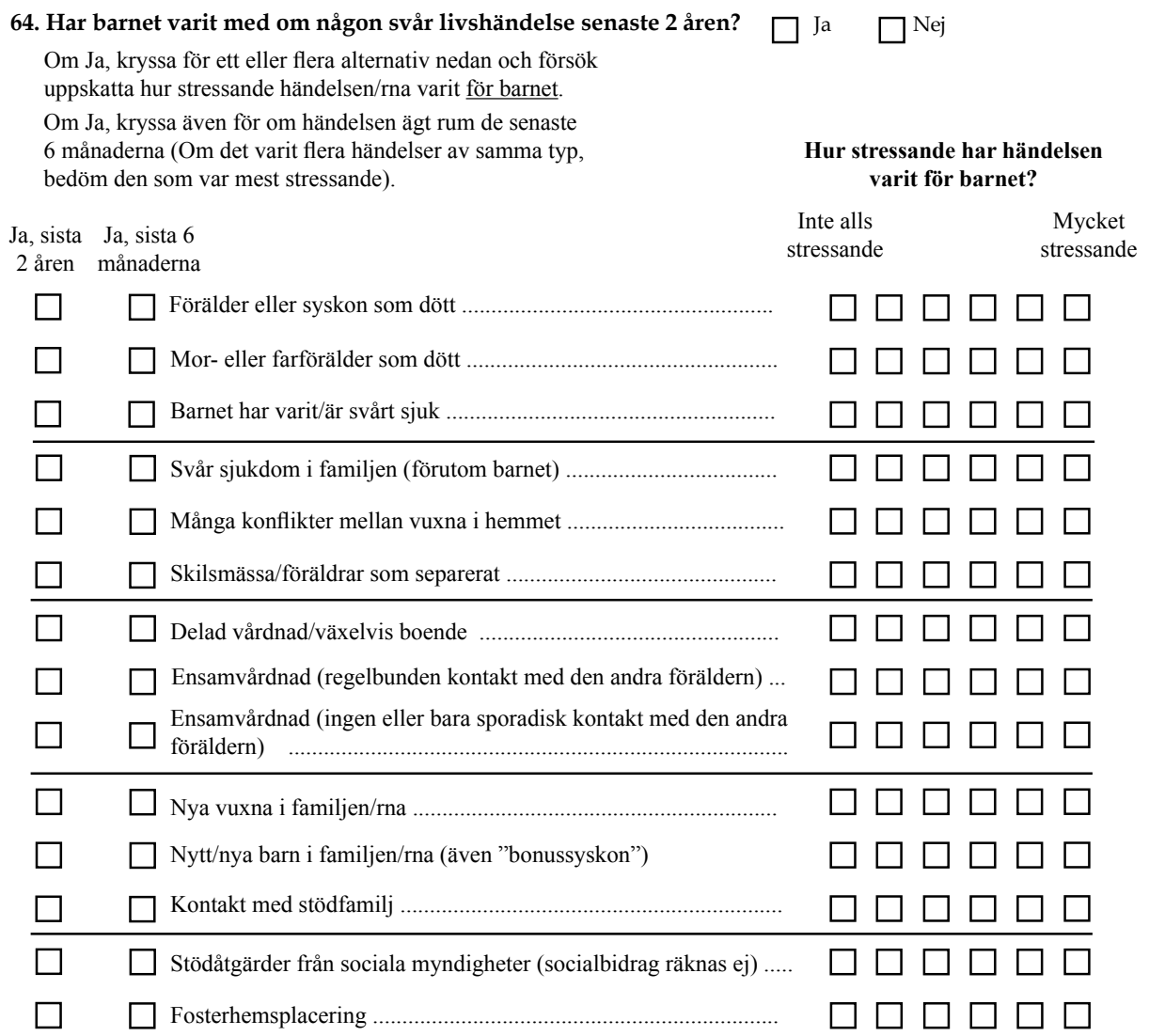

Om barnet har varit med om någon annan svår livshändelse, eller om Du vill berätta lite mer utförligt om vad som hänt får Du gärna skriva här: 


\section{SLE experienced by the parent measured in data collection...}

at birth

29. Har du själv utsatts för något som du uppfattar som en svår livshändelse under graviditeten (ex anhörig dött, skilsmässa)

at age 2-3

$\square$ Ja $\square$ Nej

99. Har Du själy utsatts för något som Du uppfattar som en svår livshändelse sen barnet föddes?

$\square \mathrm{Nej} \quad \square \mathrm{Ja}$

Om Ja, vad

Anhörig som dött

$1 \square$

Svår sjukdom i familjen

$2 \square$

Svår olyckshändelse i familjen

$3 \square$

Skilsmässa

Utsatts för våld

$4 \square$ óppen

Själv blivit arbetslös

$6 \square$

Make/a-sambo blivit arbetslös

$7 \square$

Annat,

$8 \square$

i så fall vad?

$99+x t$

at age 5-6

107. Har Du själv utsatts för något som Du uppfattar som en svår livshändelse sen barnet föddes?

$\square^{\mathrm{Ja}} \square^{\mathrm{Nej}}$

Om Ja, vad?

$1 \square$ Anhörig som dött

$2 \square$ Svår sjukdom i.familjen

$3 \square$ Svår olyckshändelse'i farmiljen

$4 \square$ Skilsmässa

$5 \square$ Utsatts för våld

$6 \square$ Själv blivit arbetslös

$7 \square$ Make/a sambo blivit arbetslös

$8 \square$ Annat, I så fall vad?

tet 


\section{at age 8}

\section{Har Du själv varit med om någon svår livshändelse senaste 2 åren?}

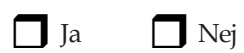

Om Ja, kryssa för ett eller flera alternativ nedan och bedöm hur stressande händelsen/rna varit Hur stressande har händelsen varit för Dig? för Dig.

$\square$ Make(a)/sambo eller barn som dött .

$\square$ Förälder som dött

Själv drabbats av svår sjukdom

$\square$ Svår sjukdom i familjen (förutom dig själv)

$\square$ Svår olyckshändelse i familjen

$\square$ Skilsmässa/separation

$\square$ Vårdnadstvist

$\square$ Utsatt för våld

$\square$ Själv blivit arbetslös

$\square$ Make(a)/sambo blivit arbetslös

$\square$ Annat, i så fall vad?

$\square \square \square \square \square \square$




\section{at age $10-14$}

65. Har Du själv varit med om någon svår livshändelse senaste 2 åren? $\quad \square$ Ja $\quad \square$ Nej

Om Ja, kryssa för ett eller flera alternativ nedan och försök uppskatta hur stressande händelsen/rna varit för Dig.

Om Ja, kryssa även för om händelsen ägt rum de senaste

6 månaderna (Om det varit flera händelser av samma typ, bedöm den som var mest stressande).

Hur stressande har händelsen varit för dig?

Inte alls

stressande

Mycket

stressande

Ja, sista Ja, sista 6

Make(a)/sambo eller barn som dött

$\square \quad \square$ Förälder eller syskon som dött

Själv drabbats av svår sjukdom

Svår sjukdom i familjen (förutom dig själv)

$\square \quad \square$ Svår olyckshändelse i familjen

Skilsmässa/separation

Vårdnadstvist

Utsatt för våld

Själv blivit arbetslös

Make(a)/sambo blivit arbetslös

Om Du har varit med om någon annan svår livshändelse, eller om Du vill berätta lite mer utförligt om vad som hänt får Du gärna skriva här: 


\section{Papers}

The articles associated with this thesis have been removed for copyright reasons. For more details about these see:

http://urn.kb.se/resolve?urn=urn:nbn:se:liu:diva-121066 